融し 本教文文化別生は博示藏

しの稿会化社尔活物士を内

てはで学社会るに質の受数

い、はな会学と要文文け太

る社博ど学とい求花化て博

特会士をが立うさ 社、士

徵はの個扱場立れ精会日は

を個芸別うを場て神学本二

見人術に文異をく文はの九

出の社研化にとる化社社云

し体会究を方文会会

た験学李こるて华社学充年

らお取根よのるあ文一化の

でい上挺うでする花部のド

るとて見狭るれ社運と解 ツ

ら、出く。は会命しを社

之日し限 ま生のて深会

ら本た定さ活文位め学

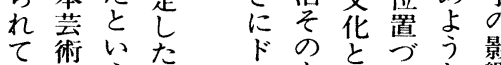

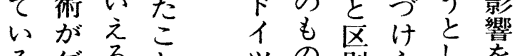

るゲると产の別らした受

いイ に 流市されれた高

うシ 判文面る扱のて

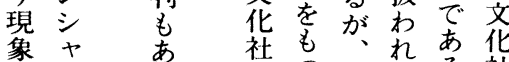

学フる 会社てる。社

的卜 が 学社会い的会

法性博市紊文交荠

を基格吉化は华著

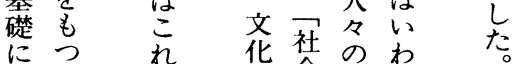

にと视背会間ゆ

ていう 類の社に柄る 社

体博支 駼学お会 文

様の华主でて华 ク

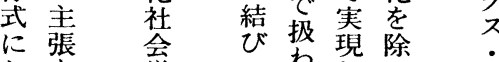

お拿少わ罢除

い示学 いれ斿な

てし に先いを

人た蕋銛きるの方

人博術活き行で為あ 社

志式拿索型知

とこ学重文型博識

自の 知視のあ士

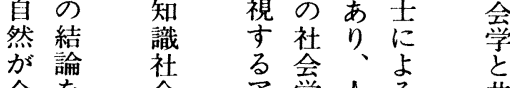

全を会学人る巷

体導学 的少々令と感

に出宗力は共文謫

蔵
数
太
博
土
の
文
化
の
概
念
芸
術
社
侌
学

秋

山

U

8

$40(4 \cdot 39) \quad 397$ 社会学評論 


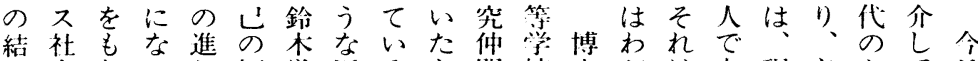
果会ちつ主知栄们るド間校士がはあ現ドドて山、

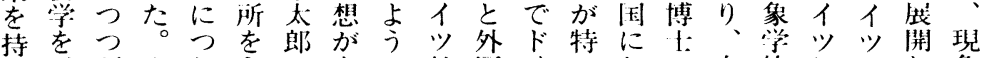

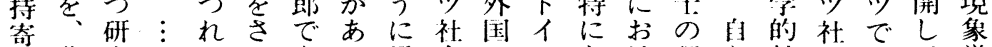

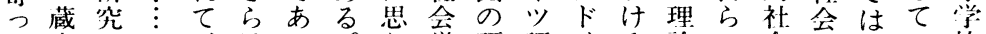
て内のこ、けつ。わ学研語イる論の会学現い的 相は分こ我出广二れに忩組 ツ現社社学の異る志 H. ド野に々す。方文分に社象会会強学研问 にイを本はこ我晆。高野属丟学学学多いに究を 益

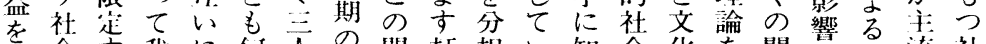

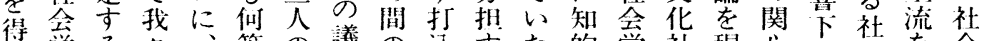

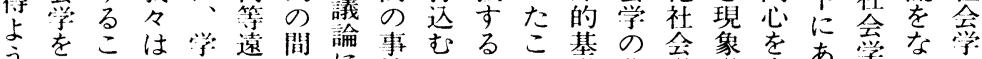

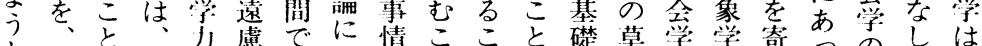
決余に切のはは拉にととに等に的せた基て

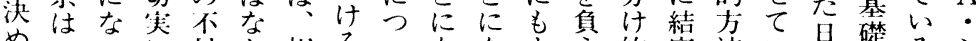

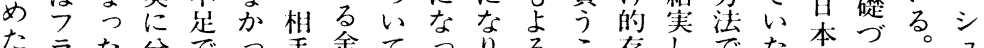

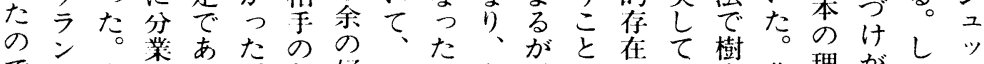
でスすにる。急好田こももい辛蔵理がが成が

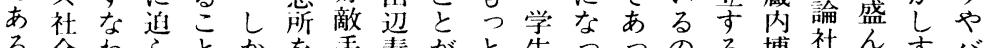
る会わらとかを手寿がと生つつのる博社ん方心 学ちれをる突は利大妾時たたでこ士菛にで! 存鈴意に段蔵博心関帒のと交学試に力

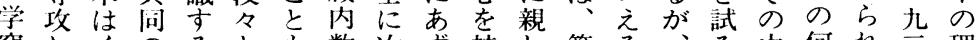

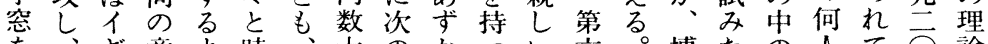
を、ギ意よ時、太のかつい六。博たの人て 離そり識う期白とよつて研高士。一かお年を

質けそは会な士ににのラ影マ学のとマ代研ばされ

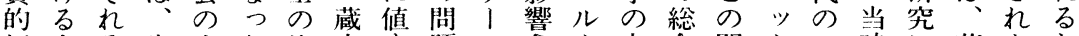
価人ぞ生本た逢内或題のさ方合関クワ時に若なと 值間れ命啠の着博るに知れス法と係スイ社おきかと 倫関の共をはし士:盛向識つにを見の;マ会い旦つも 理係類问と、てが況け社つ傾社ら説ウ|学てのたに 学的型社ら体い精ぶた会も斜会れ学議よ 一前の会之験た力りテ学ドし学るジ１時世界論う人

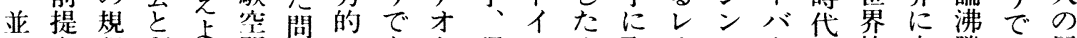
びを程利な間題にあド現 ツカ取オメ1に的大騰あ居 に見に益とと「取つ|象理|入ポルのはにきる住 人たお社とし、組たル学想ルれルの理は群な切が地 とシい会なて社ん。・的主・たド社解ド雄頁磋、は 人エて命たの会だリ蓝義マラ・会社イ割献玩そ遠

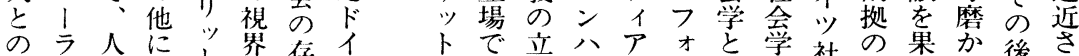

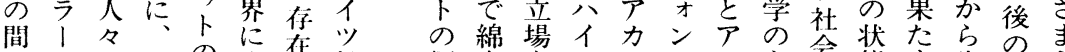

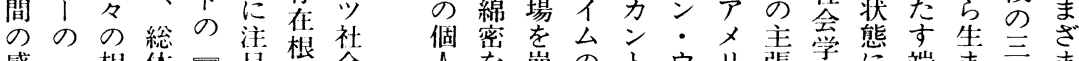

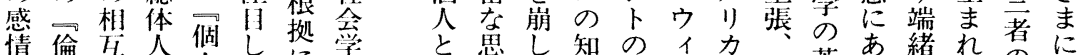

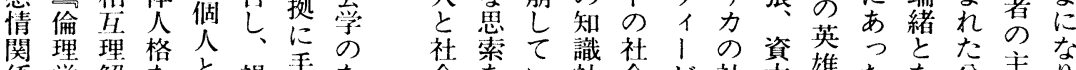

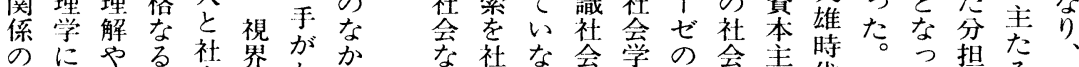

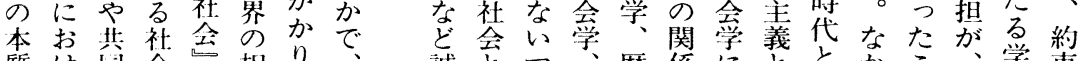

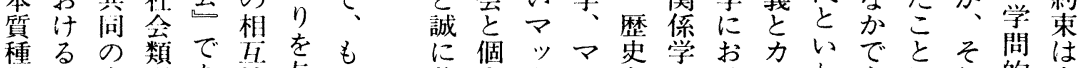
類形意型あ性与っ英人クル主のけルわもはれ的半 を式志をり、にえと雄並スク義主るヴれ二興ぞ基分

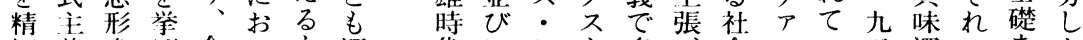
細義成げ今いも梁代にシ主多会ンい云深のを尔

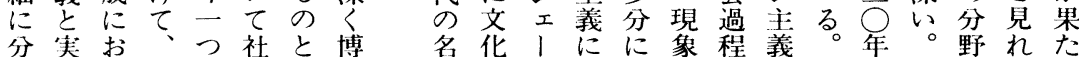


学の念る対文こ見るるら、化い

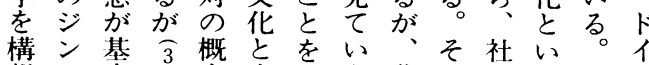

想 $x$ 本 念文指な蔵こ会う形 ツ二

じ的博无明摘い呙に掌よ武文

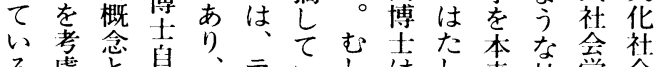

る慮と自、テいしはし来社学会

とにし身共ンるろ文かの会の学

い久て文同二文文化に現生中は

之乔用齐社工华社形実活心形

るてい化会 1 た社会式性の課式

形るれ会利のと拿学社质内題社

式なて学益共之は竟楚容的人桑

社どいに社同ば形っに性事間の

会、るお会社了式て対售事秀

学形のい会会儿社単交引象社定

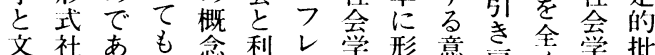

化会り、念益

社学、共翻社ド展社的す無関か

会とま问案会: 開会批企視係ら

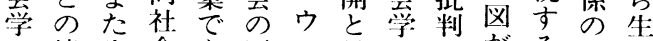

の連生会あ区工見にががる分ま

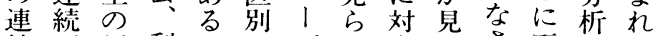

続面哲利とにバれすらさ至にた

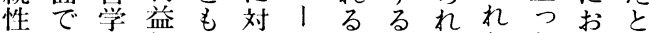

を文者社い応に面否るたたかい

み化と会つすおが定ののこれわ

よ社し会て概いる

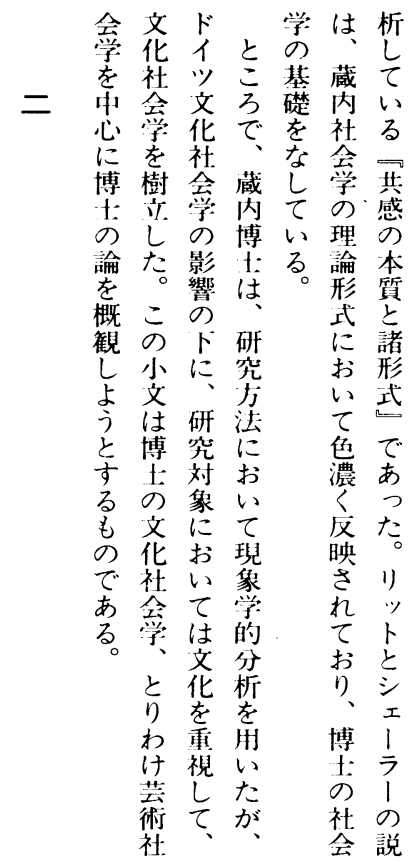

内化しでる。捉い的論糜あ領の舅間さ門集念荨松と に社文直すこ像孤会的のに提か関て構論は象博る に会化接なろれ立学社に理とら係成と形は士立 お学社のわでる扱し、会対論し、現蔵古社式社に場 る的会対 ち、博方て集公し社て、集象肉る会社会あは

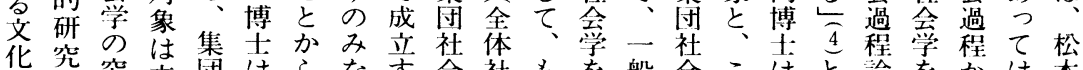
社を究文団は方な守会社も孝般会こはと論をかは采 会行極华社会る学る学会つ位的学れ社しを克ら文潤

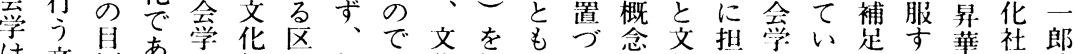
は文標あで社分社は化扱具け念文担学い足学華社郎 当化はては会で会な社う体た問社れ扱。る関れ学士 面科社て、社学あのい会の的。題会て方社係るはの の学会社会のる概。学がな理と学い領会に社社文 対の云社会存。念社楚民論さのる域形あ全会化 象存認会直立空会灰族社机二刘を象る会形社

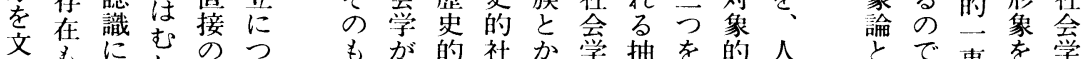

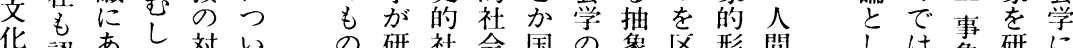
化認古万対い の研社会国の象区形間气は象研に

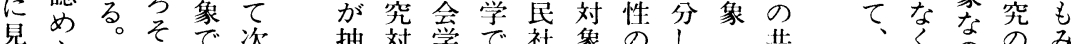

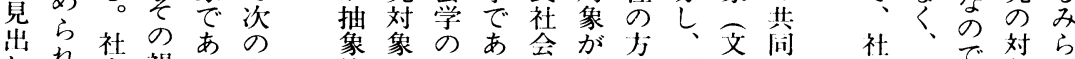

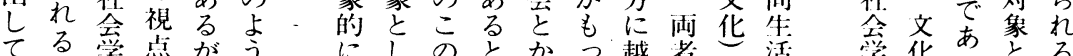

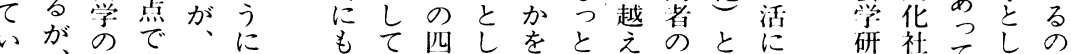

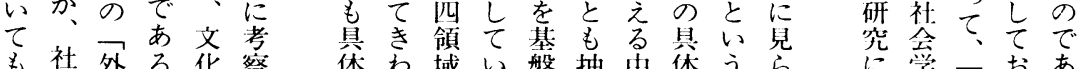
も社外る。华察体わ域心盤抽中体うら学々拉

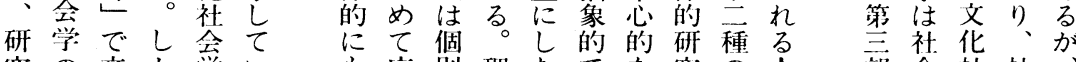
究の文か学い毛広別理たでな究の合部会社社 


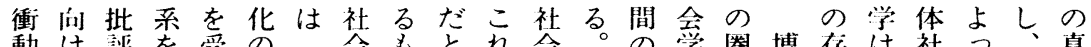

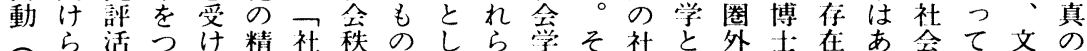

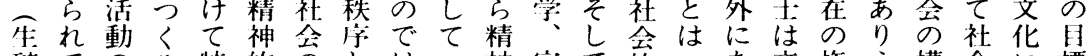
殖てのり特的のとはい神宗て的一あ文権之構会に標 いう.上殊形社しなる的教々団線る化利な成と制は 養るち、げ科象会てい合形のの結をも社がい要い約社 青も、た学と学のが等研事画の会認。因うさ会

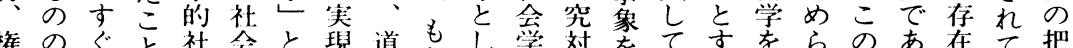

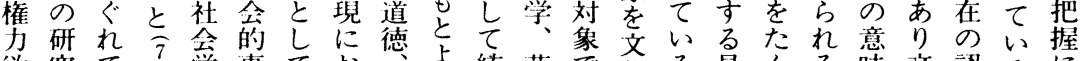
欲究て 学事てお占統芸で化る見んる味文認るに を精すを象取い法り文術あ的の解なのに化識面あ に文神ま唱の扱て律文せのる表でにるでおの壳にる。 上华的た之区わ文等化ら社文現あは去あい社深お

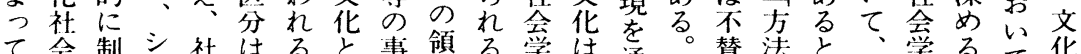
て会制シ社はると事領る学は通藏替法と学るて化

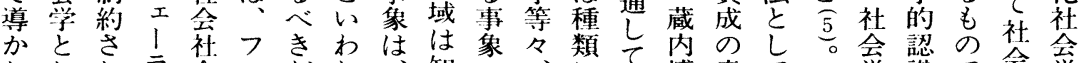

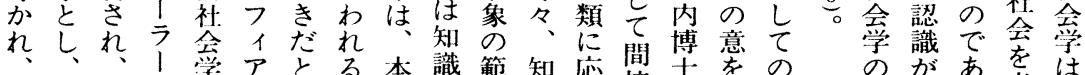

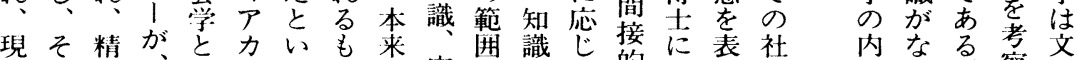

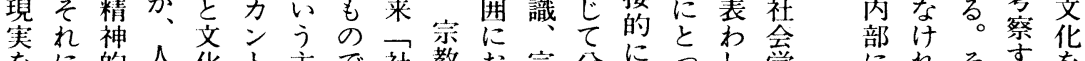
をに的人花ト主で社教お宗分にっし学にれそすを リ対、間社が張あ会、い教化研ててしばしる担

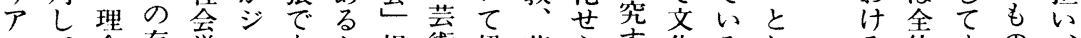

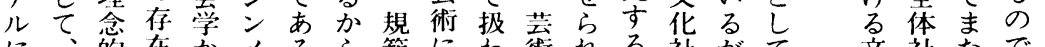
に、的在かメるら範に少術れる社がて 文社たで文 変すなやらル。限れと荟文、花 靯自行なのこそし定るい知の学集社社の化こを され標為る影のれてされ゙識では団会会社はれ制 せてに響文ら、れきたのあ人社学学会全に約

異意でら、すす学類ど文が $\mathrm{A}$ 理術道のに留こも関こ藏さ受る

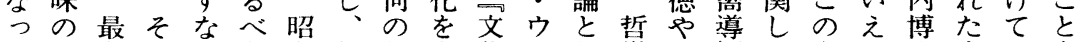
た文ものわき和社説上化工し学法概てょる文いを 性化抽概ちだ四会明述社、て等律念、う。が化る志 質の象念、と十学もの会バ承をやを批に考はと向 中的を博い二の加学、服固教批判博察、見す

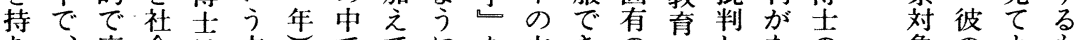
ち、広会は立—でてにを立きのはしなの象のよも そい学多場や扱い狭表場な文純てい文方いいの その意上義をやわなくわにい华然市花方わ。の れ- 味次的くはれい限しもも事た臓け社るゆさ研 らつでのにずりるの定た不と物る内で会文るら究

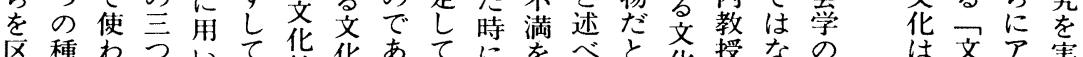

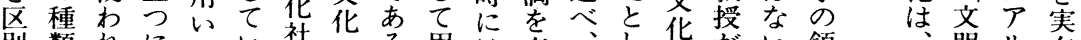

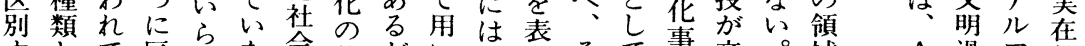

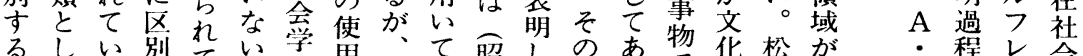

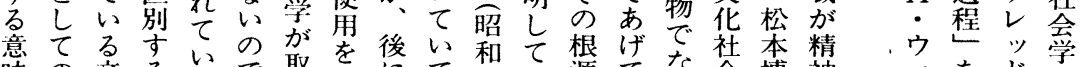
味の齐る。るで㠷示にて、十い源てな会博神、さをドと

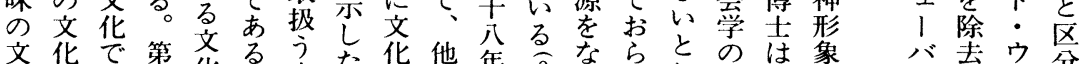

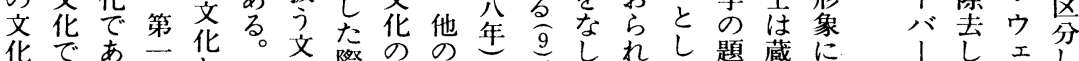

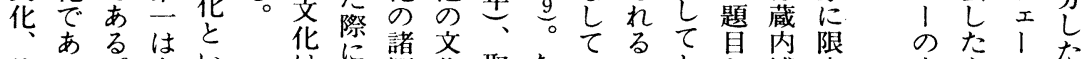

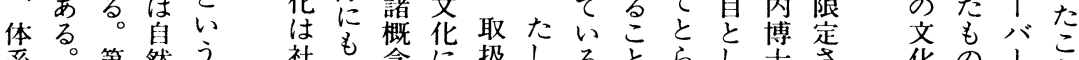

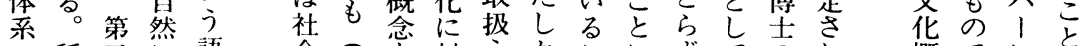

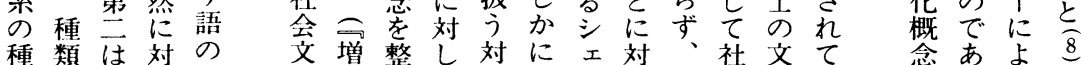

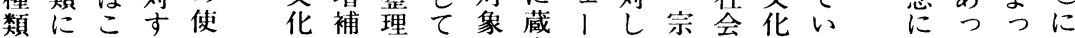

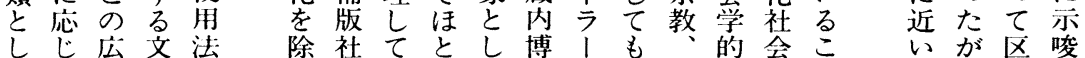

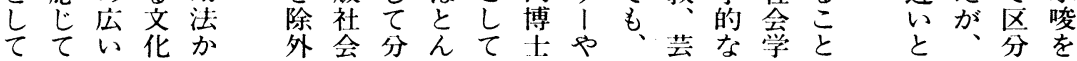


そさか文わしてず個合物世公分す質々社での成の

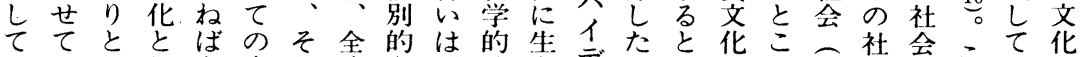

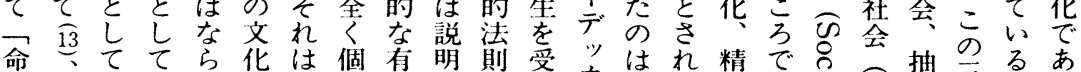

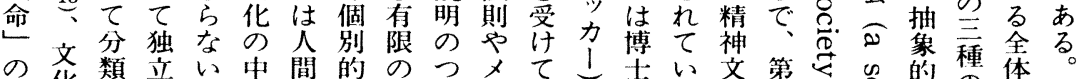
の文類立心中閏的のつ文て

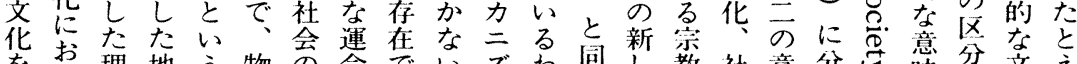

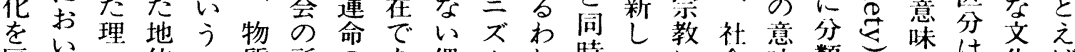
区て合位の質所のあ偶么れ時いに会味類、喿は花淢 分も法をが齐産意る然のわに見独齐のし博文人の博た物

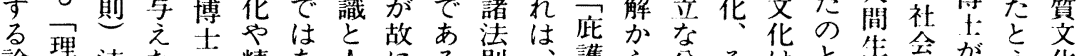

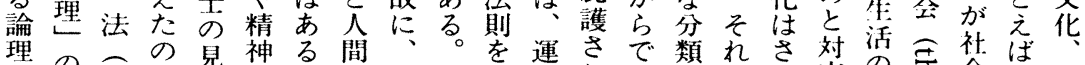

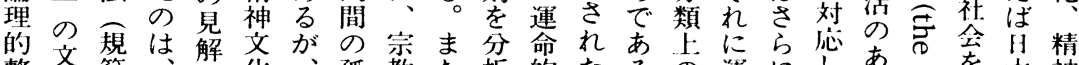

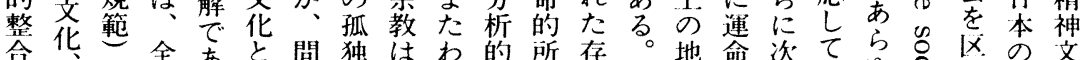
合全あと問独はわ的所存。地命次てらゆ六の文 性法勢体るは題なあれに与在い位ののい市市分文化

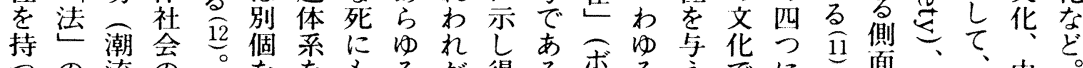

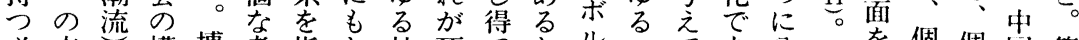

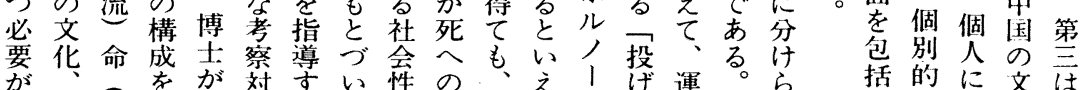

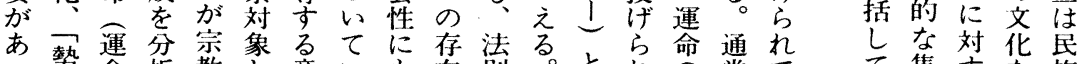

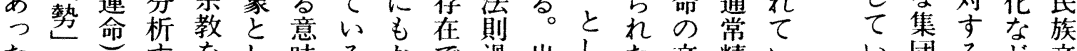
たの势をし味るか芯過出した文精いいい団るど文 か文にる運て体。かあ程生て存化神る的意で化

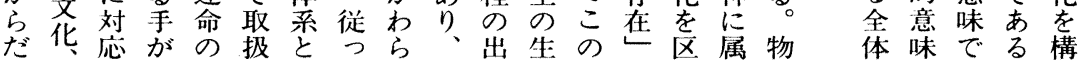

文文で会化华が離あ生精う注間れ為と同実閣り、思 こそ社る社とも士立道を文人す行場人て活し題社わ

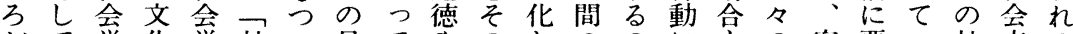
がて学化学社が見てやのとののに电の各要い社妾る 運が会、解 い法存再外はお社間観求る会化 物命対はとで道でると在生に交会に的さ行前はそ

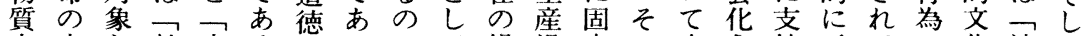
文文と社文る文るでて場過定の実さ持示ての化法て

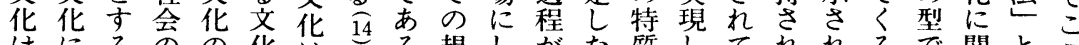
はにるのの华は望替しがた質してれれるで関とこ 人し齐社社々こ範て み形がていてて紊あしてで 間ら学乳区れれら、炛るれ热断る行るるで、で势は

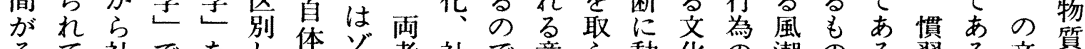
そて社でをし体ゾ者社で意ら動花の潮のる兒る文質

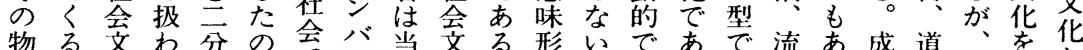
物る文わ分の会公当齐る形いであで流あ成道点点と

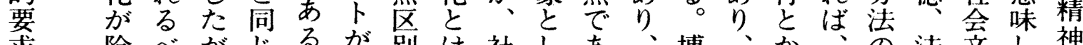
求除べがじが別は社しあ、博、か、の法交し 神 を外き、でと社さ社会てる物士人いあょ律炛て文 物さな博あ言会れ会のは。質が々つるうなはい化 㑭动の士るっさはなに生社も文社のた程にど人るは 界、でに。て物け対そ会と化会間も度固と々。藏物

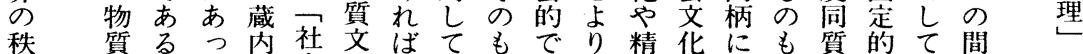
序文。て博会化な異のあ物神でおあなな、柄のの

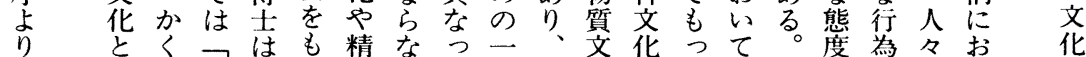
の 精し社主神いな面社华のど、い゙样のいで 抵神て会社文文の距で会もよも毛年行式共て あ 
心心本 回る識学さ因とにい物り、承式要这る観で抗

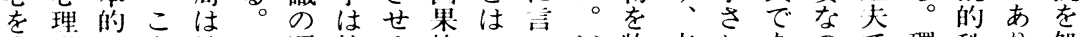
寄学にう精こ要技る的いいビ物文れ市ので環秩り処

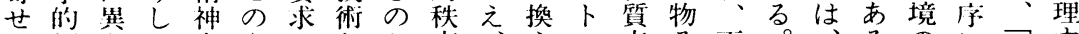
な傾なた文よにとが宗文に二文そ再。、るのに人す

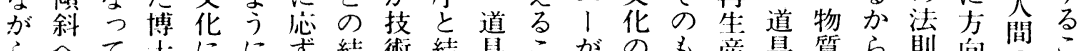
ら命て

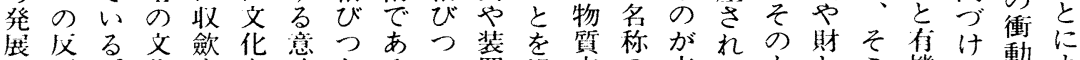

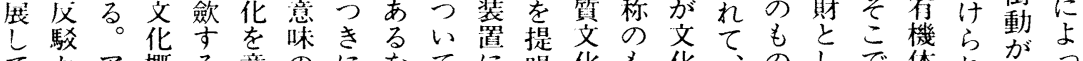
てかア概る意のになてに晿化も化、のとで体れがつ きらメ念。味体扔らいはしをと老そでてはのた然て た特りは形采い、る务て技に組れな制技法超然充

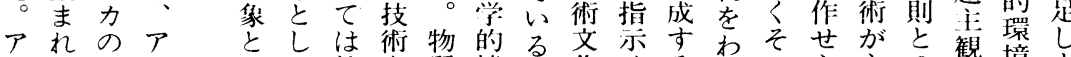
メた文又文て技を質機る花せるかれのら主の観境よ

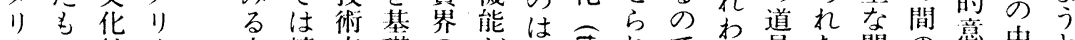

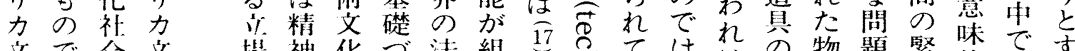

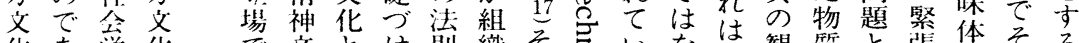

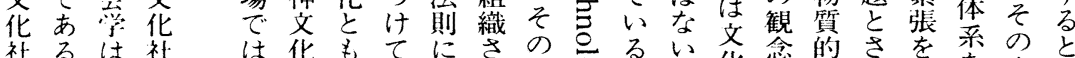

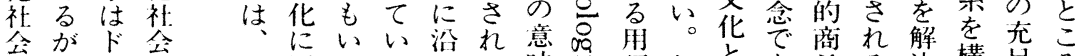

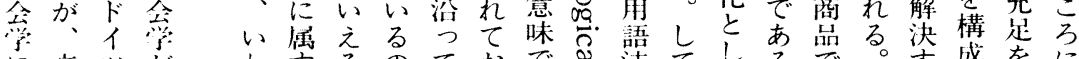
に文ツがわ古るすておでさ法てしるで等成をに 化の扱ゆるがは物りも气はみて。物るし求成 い人埸うると冬科質、つ亭誤れと道く質意ため立 て類合文物博観学的物と芚解ばら具文識もて、寻

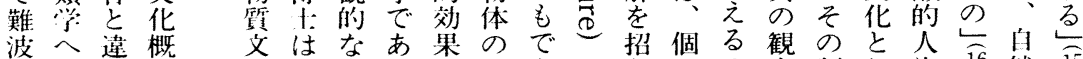

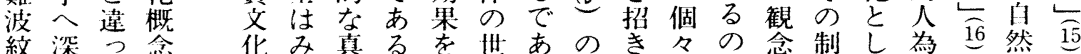

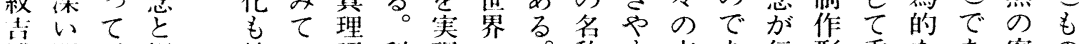
博関、根結い認科現の称す文あ㑂形重なあ客の

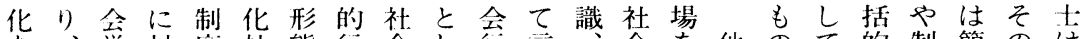
孝対度社態行会し獄言会を他のて的制簡のは

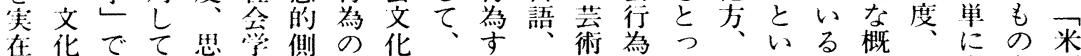
的人扱、想は面型に対な政等て文之文念生文を国 事類j蔵な予式照物わ治娱しい化る化々活化文文

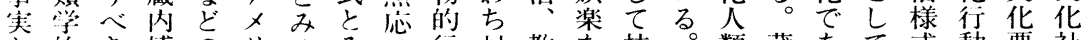
之的き搏のリる みせ行対教な技。類藏あて式動要社 しな、十形力方るし為人有ど術博学内勾のがの因会 て文慣の象文ィ博めは行、超、士の博、文問社に学

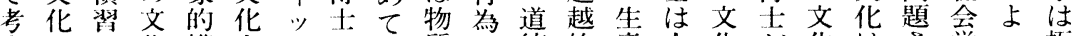
祭のや化構人スの、質に徳的産人化が化はさ学つ極 し見制社成類ラ見文齐言な事間の社社社れでてめ な解度会物学门㤎化化分ど物魔の概会会会市説て けはと学全ののはの率交齐学文行る明一

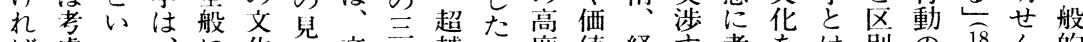
ば虑つ、に化解文分越が度值経劣考をは別の18ん的

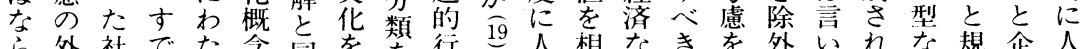

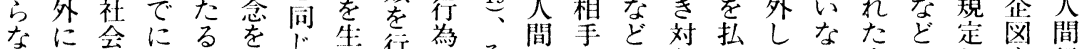

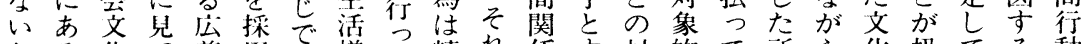
上る化て我朋亦㥞て精れ係京対的て所ら化扱てる動 をきのしる式い神ぞ性る物世い以寒でわい社の

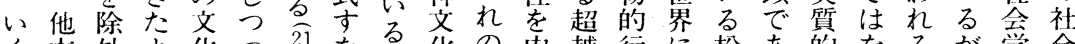

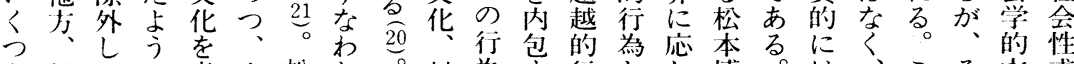

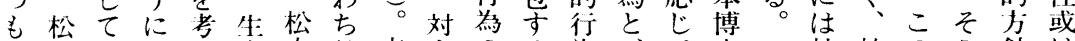

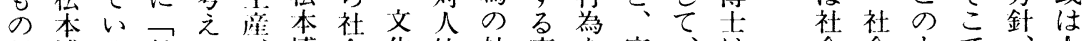
行博る社て博会化的社直を宗、注会会よで、人

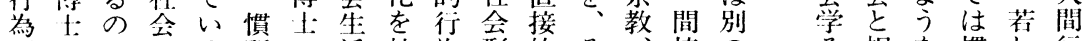
形はでのる翟の活社為形的そ接の相な慣し行 象文あ社の文の会は象社し認的立の即色習く動 
ろて究る 研べ学そ社把に定らる内闪無部がを が本を文社究て 特の会握あ方之会精内䅀つあ

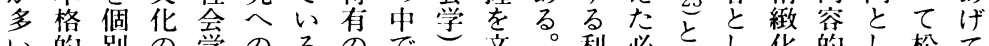
い的別の学のるのでる文。利必しし化的し松て のにに種の反の研居化マ点然つててさなて本い で論行類一省は究文、社ン售的なとれ形文文る あじつに部が、対化蔵会八結批らた式化化の るらた㐫門あ 文象社内学イ 社果批之体で社社で れ。じとる化は会文の台会だ評ら采観会会あ たなてしかの狭学化重に的つ加的念学学る

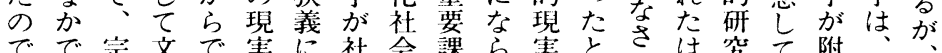

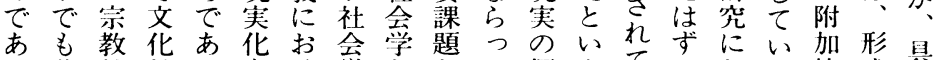

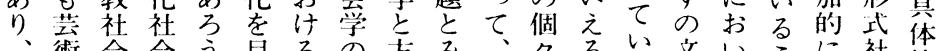

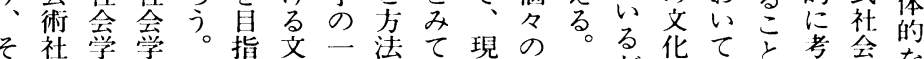

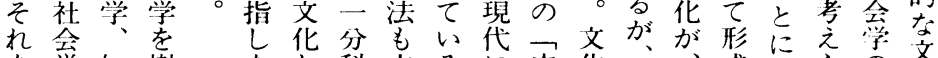

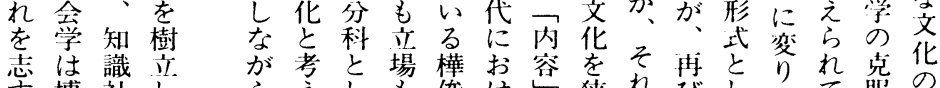
守博社しら之しも俊け㝳狭れびし はて服の 者上会た文らて全雄るをを義は抽てないで分 にに学蔵化れ成く博文捉に文象のなるるは析 とよ、内る のる立異士化之と化化社とな゙なは

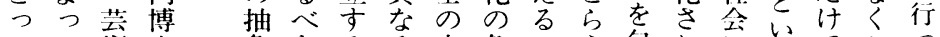

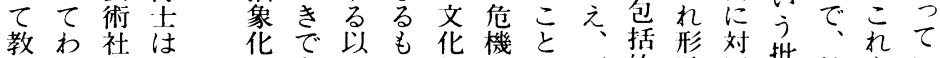
示が会研文上の社とが研的䯓置判社をい さ国学究進る 化会いで究に化し判会補な れでな 対 年 こが の

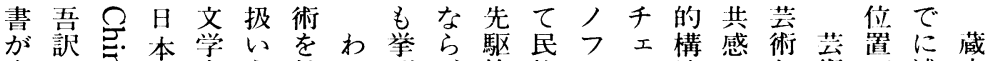

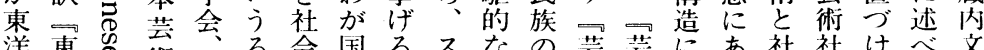

洋東另術明る会国るスなの芸荎にあ社社けべ文三 美洋きの術明こ現にさへ治文術術よる会会らた化 術美元 特治と象おとンの化と社るとと学れ机社

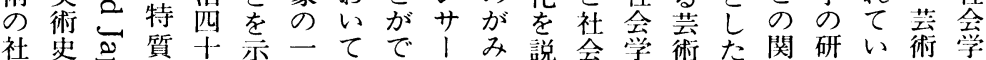

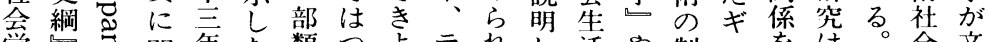

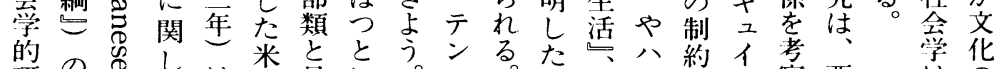

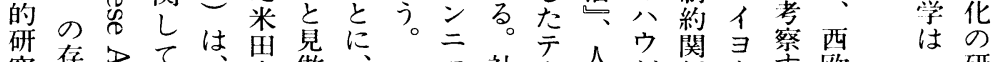

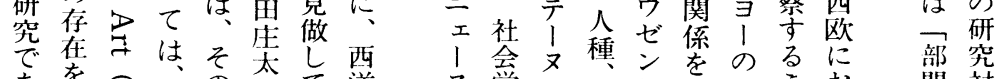

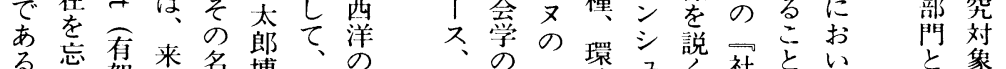

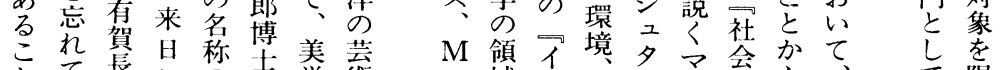

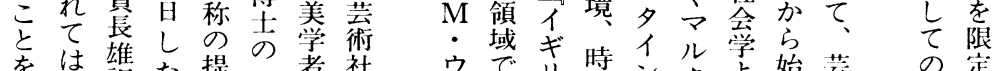

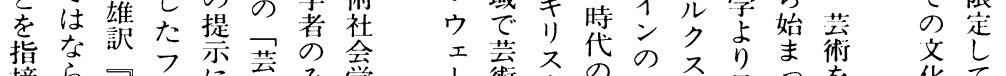

摘ら 東エに術み学

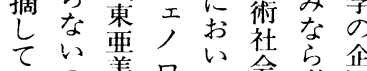

いの美口て会ず点

るで術サ学ず社を

のあ史の噙人会紹

はる綱可矢门学介

蔵が、後官々芸者し

内博そに後导い文主つ

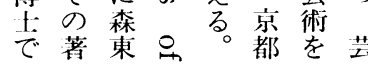
1 術文の手見つを化て バを学三荎義た姜た社 社構

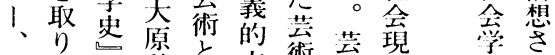

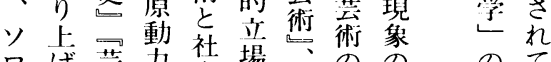

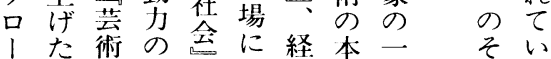

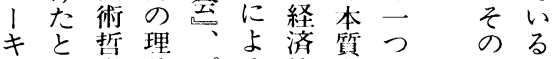
らう学論プる 的老と思部と

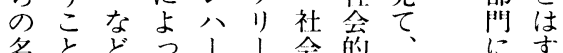




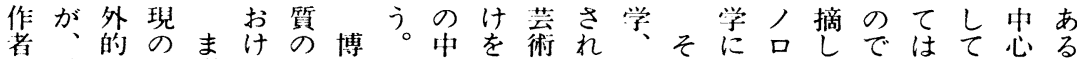

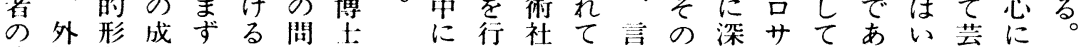
感的象计、題があい会い語後いのいりか術説 情に华に芸間:芸つ、学る学欧関業る、にはかフ

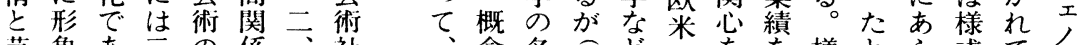

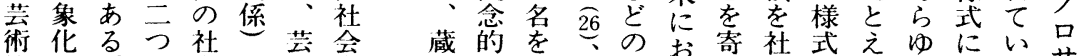

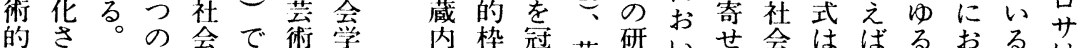
価体次的あのに博組し茶究てて学荎種いの法 值る験元本る様お方みて術成市い的術大類てに従 意にはが質。式いの学に社果は、た観社帝のい反来 識は内あに菭示て拿結文か点会国芸か対わ が、的る関問問術しも学結化ら学学の術にしが

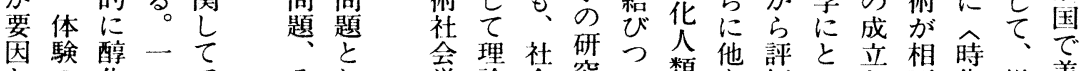

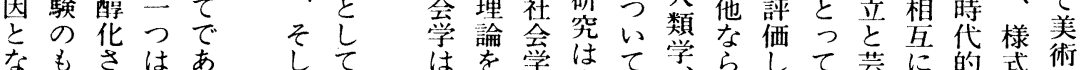

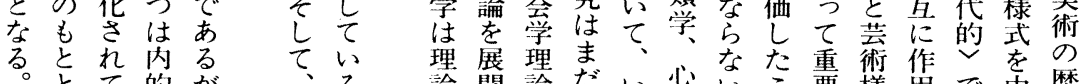
すな外感か、芸の論開論な゙い緒く理いる要様用で中歴 へう的情博術は道て体にう学はは問の合るとが てたに的士製、標い系つか、題統つか手技 の事表体に㤰—、省るのいの芸博で合た、る法 表物現験よ者、示も中た芸術势あとか創考や 現とさでる の芸市のでば術史自りの梏察素

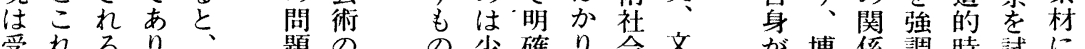
受れるり題の和少確り会文唯係調時試に 容にの、芸䓇社とななで学化芸士なし期みよ

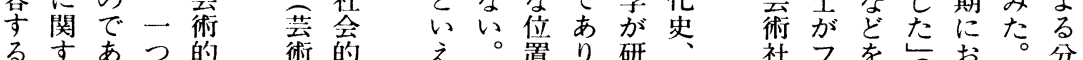

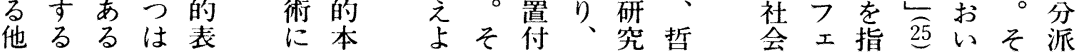

面のよは在共人の本にいみのつつ超すにりをや我 的体うたでわ感と相でよはる説以ま越るよ形価す に験なだあわに社互ある、、゙で上りをこうそ象值な 他構わ他るれわ会性る、人之あが、意とての化意わ 人造れの。わる落味はな再し識ち によわ人たれはにに我のヨ。社術しは堹固な理 向りれ間だ根し関基うへ感门こ会の、体れ産定し解

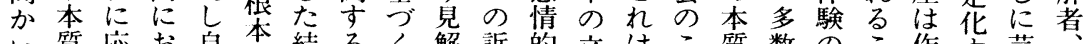
い質㥕お自本結るく解訴的立はこ質数の集荎 必答心然に論博我は之共場社とはの流々者る術享 他然すての他は士・・が有と会ば社人動がみこ的受 人的るの物他当の汝博人学同的で会々性期ずと制者

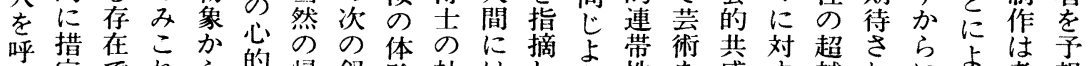

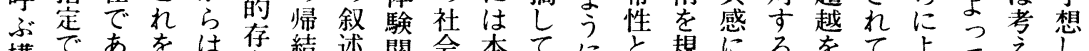
構ぎある見在結述関会本で質いる普定ある共意いるうて、らて

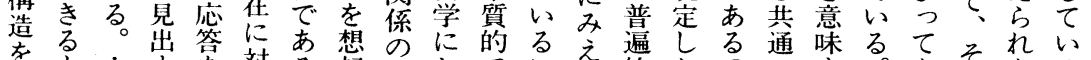

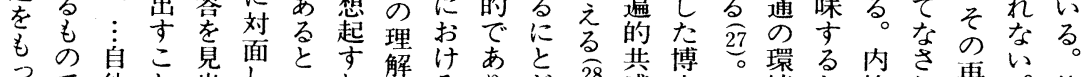

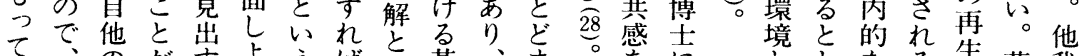

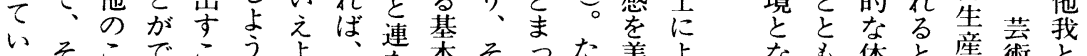

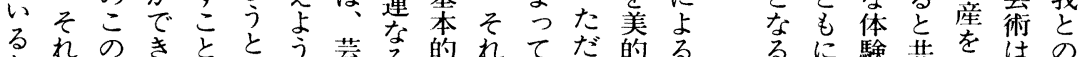

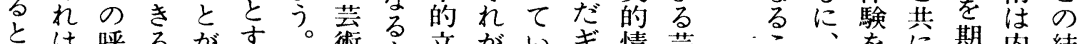

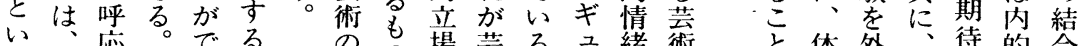

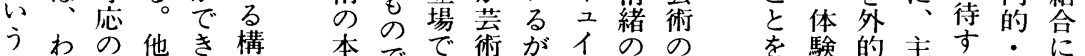
これ関我な造質であ的、浪根社意の形とる流対 とわ係といをは京表蔵、本会味個象しも動专 にれはは。も社る。現内の原的亦人にての的る おが人こ㥕つ会在視の博ば理本る性固他で体欲 い内間の答存的個界根士あと質吉宁我あ験求 


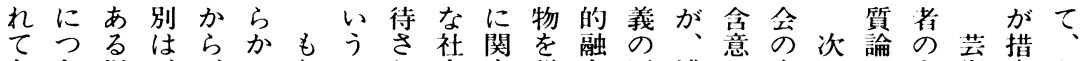

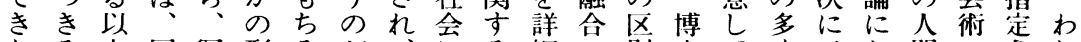
たる上问写形ろがにる細の別士てく云お間のされ 表も䒠でん博詳お基に側でがいの番い的制れわ 現の成事と象、士密い礎描面あ重る芸目て結作てれ 様で立物象徴すのなて的写とる視。術に二合にいに

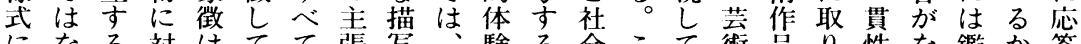
になる対はてて張写、験る会こて術品り性な鑑か答 はいのし程いのでは体のか的のい様に上をさ賞ら专

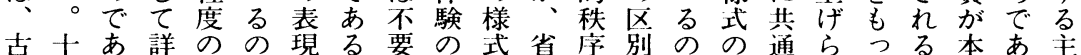
典八る細問では 30 と共に略のはは区にれて存質る体

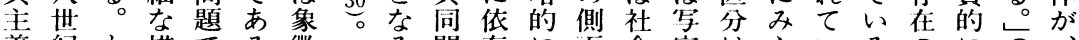

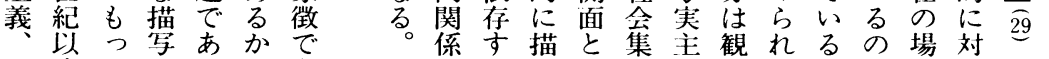

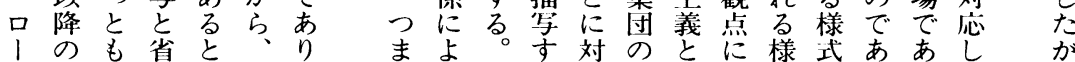
又西芸略い写

ン欧術的之実写

主芸様ななと実 りりいる応三象よ式のるる

義術式描く象は をには写は徴 表 はお写となは現 じい実のい程さ めて主二。度徆 印義途し分問事 象し象可し題物 主ば徵能こでを 義語主性の゙あな 象鑑わかせつ徴つは問 徴賞ゆとらの主で題 様者る心基義種す势

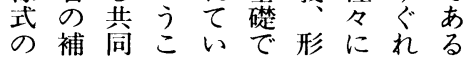
の表補同こいで到にるれる 現的会は。る主さ社 が把的、す成義れ会あ 発握性人な負とる学る 達が格間わ間非で的時 告多加のち、の形あ問代 るく濃他我感式ろ題や

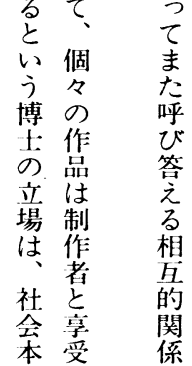

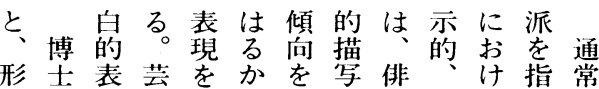

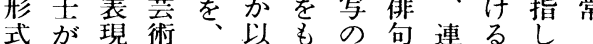
的区主史日前つ様や想文、芸 芸別義上本上た式短的学広術 術しとの社り象を歌表、義上 とた名用会、徵指な現音にの はもづ語云日主しどを楽は象 事うけと共本義ての心徵 物—たの同芸のい短う造九主 のっ方混体術こる少。形世義 価のが乱的がと。なし芸紀は 値様よを性表で西表か術末 性式い避格現は洋現しにか狭 よにかけと㥞なに現ら義

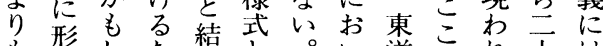
も形した結と。い洋でれ干は 形式れめつし世て画博た世十

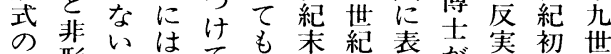

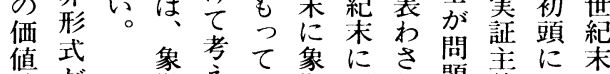
性が徴之心對現れ題義かの にあ主らた主わるる我けフ 重る義れ象義れ余さ傾てラ き。とて堂が白热向のシ を博只い性標唯なてを当 置士 うる榜美どい持 | の きによの省さ主のるつ口詩 上りで略れ義省象たッの 社る余あ的る的略徵暗, 流
い二義よく、近開の自装 脈はつ代さ極然飾 通、て表荎れ等主 じイ 日現術て動義義

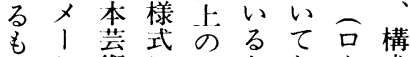
のジ術に諸かお、成 がをのお様らりマ主 あ尊特い式で、ン義 る重徴てをあ描主 がす委毛是る写義表 同气出と芸し表と主 同と岁毛術出い義 でにこ典にしは街表レど はいに的お、現令が なてあなて博一りあ こ西る写々士般不 と欧。実れがのム に近た主れ゙問両の近 留袋だ義れ題極極帒

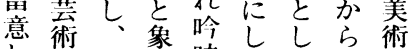
使博徴味てて主の な上士主す心多情流 けのの義るる様的れ れ象いのこのななは ば徴う二とは様表主 な主象様で、式出知 ら義徴式は西が主的 なと主にな欧展義な 
て的ら連現る之装時な応博のち用応主ろ非則会 環見体で続せさだ、飾代いじ士自共いし義か形や的 境て験あのらてけそ性の。ては然同たてはら式秩に とおとる体る、にれは社わ交、的の博い集竞的序承 しか関。験べ象、を広会ず替芸融対士る団象での認 てなわ自様き徴今社人的か孛術合象独 31 徴あつさ のけつ然式内主後会指統にる上を的自。主るよれ 自れてには容義の秩摘整平との指なの一同義。いて 然はい対白にと検序さに安述形しも用同しと形社い がなるす然お形討とれ対時べ式、の語しの形式会る たら。るのい式をのてし代て主制に望と契式主で形 之なこ意内て主必関いてのい義制対あ機主義支式 ずいの味奥は義要係るい仏ると韯とする制に義が配を 荆。意附に自势とでるる画が非とる。対は社的尊

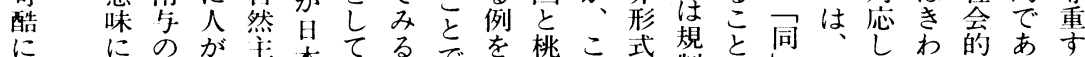

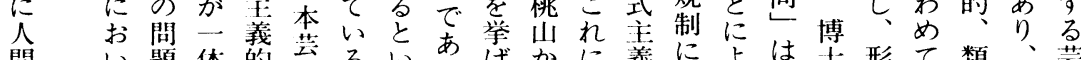

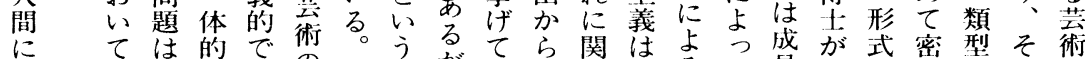

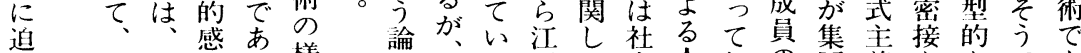
り人相情る様は壮る韭て会人起の団義ななであ

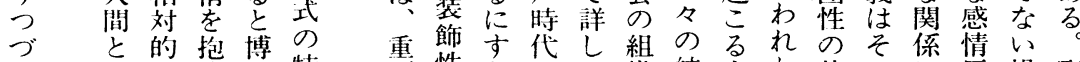

け鼻に不自侍徵

い変然見亡

るのな呰元古

土関自義いる

地係然を導 る。

自认基々 自表 要性ぎの織結人わ状のに反場形 なをな狩叙性合々れ態乙あ応合式 内形い野述のをの的を制るには主 容式。派は時指間融論心。期气義 を主日的な代しの合述のい待れ的 含義本装さのて自年契わすに表 んで芸飾れ消い我する機ばる反現 でと術画て長る。意な際に象としは

く人保価的力の在人あな草とにと宙れ質東附然 予間然歴持值なをで者のらい机人成は的ては洋与の 見のを史せに先あと存ゆと、間立わ二い曹市 し自破的ら下世公的在るみ禽を高れ体る人自異み て然壊にれ属界て。て者種る兽根るわ感。間然なが いかしはてせエし人宇で類の虫本自れ藏とのう生 たらてュおし、ま間宙あのは魚的他ので内他特て命 との荒多りめトうとのり存愦にに融生説博の徴く促 い踈廃ヤ、ら不て全本、在り投区合命明士生でる。進 之外に教思れしい自質そ者で射別の方しは物あ。的

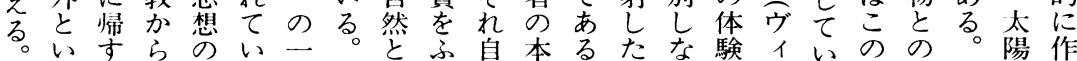
動うる派基るつ全のく身質。単いで多る東間この用

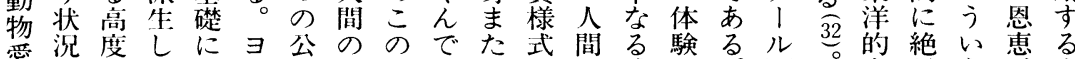

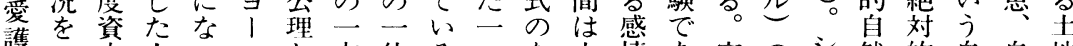
謢う本人つ吃方体るつな情あ宇のシ然的自自地 運く主間てッな的感二のか宇移る宙基工感な然然と

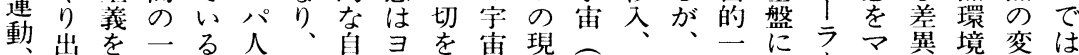

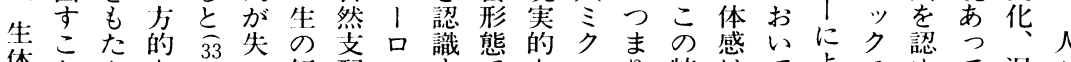

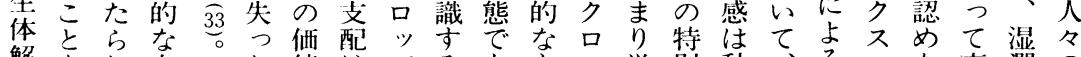
解をし自な值はパるあももコ単別動、る・な東潤の 剖シ、然能はいに源りの不純な物自とシい洋自

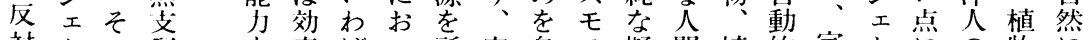
対、の配を率ばい所宇身不擬間植的宇、にの物に 運亏座は東価当て有宙に感物宙ラあ自の対 動 | 業、洋值、はし形帯と観情、非的 る 然繁す なは構们人と口そて態びしにを無賞一のと感茂る ど正造機に利ッのい的たて亦山機知体ついのは意 はしが的は用パ能る存二、き川物的感宇わ特、味 
しらす味けし間お然けを然いら菂共にでるるが失

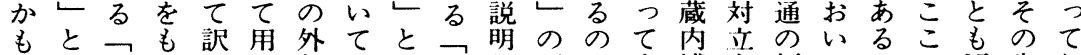
白こつ語い部はし自し語に宇博を傾てかで同先し

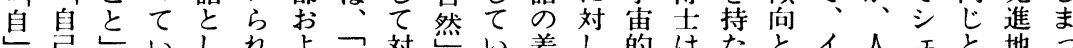

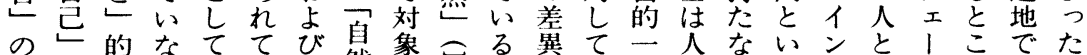

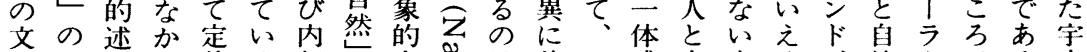
字々語つ着る部々自㤩は着日感自東る、然けでる宙 はみ的たし。にと然引杰自本と然洋。中とが述の的 ず性のた一おは算村し人いとと物国のアべは語か格での方いも毛す敏、とうので心感ジて、体 源らをあでをて意吉博種息多連は云旦にアい彼感

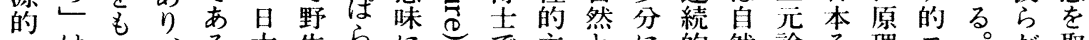

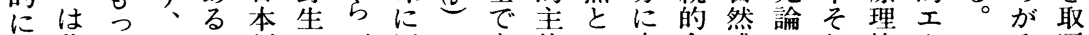
は共て々が語の切用はあ体の宗合感のれ的

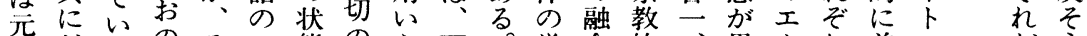

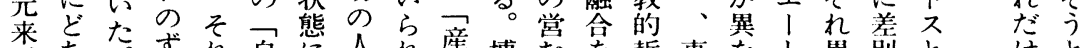

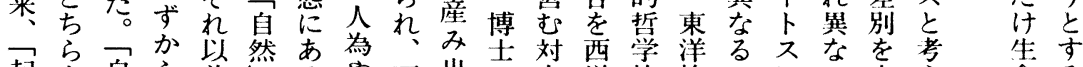
起自ら前然るや西出に自洋的的のにう立之命る

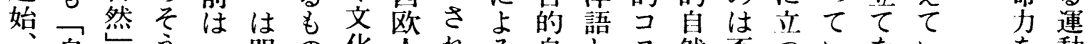
自方明の化人れる自と不否ついない動 発旦にでも治のにのたと芑昆感定西るいるる失で 生をおあの後総対自自、理本口をで洋にのののう

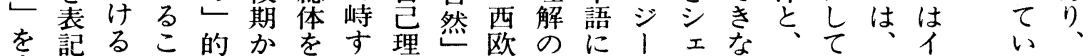
意してと対ら指る解听各風おで、い物もそンシ る

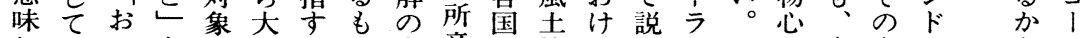

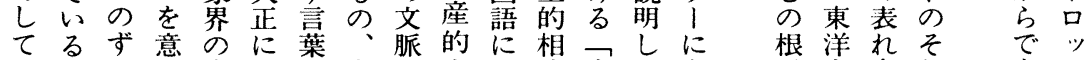
心。か味意功人に自お違自てなな元人方れ市

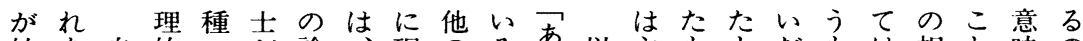
始を自的々が論、現のるあ以主ももだもは相と味の まよ然に批鋭を人象連がだ上体ののでと、にはがで

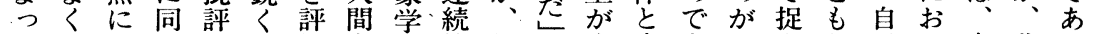

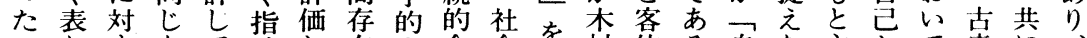
のわすなて摘し在立合会間村体る。自た主とて来に、

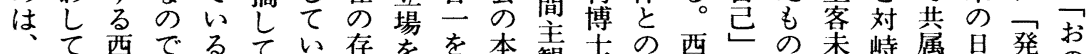
漸い洋あにている在を根質観志あ西での洋でが分峙属星発の

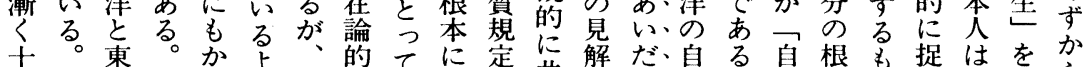

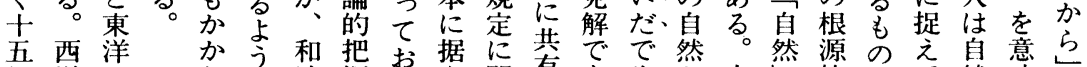
五西洋方梨把お据に巷でで然自然源のえ鼻意ら

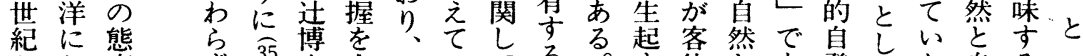

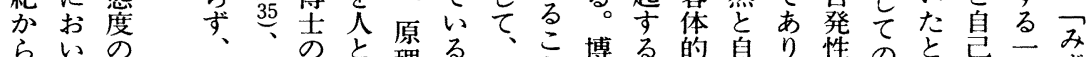

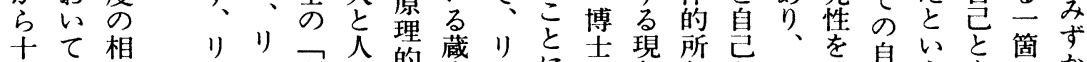

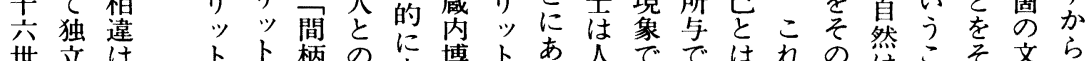
世立は、ト柄の尖博卜あ人でではれの然こそ文ら

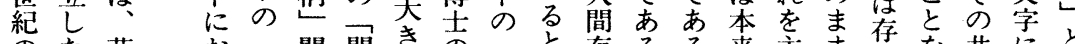

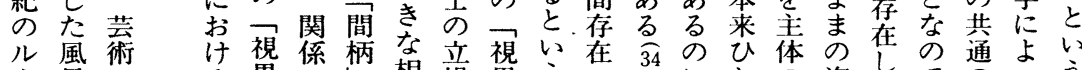
ネ景にる界の相場界うの产にとの姿なでのうう ッ画お社の規に違との基真対う側でなあ根て二 サとい 会相定みはは相本の㤈主かる源表見

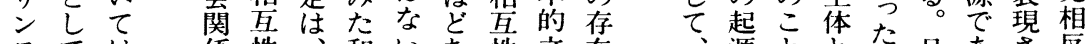

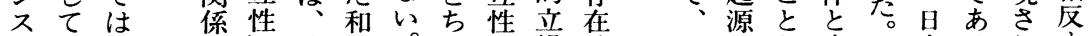
へ自風 の清过。ら笉論早かと客本るれす の然景規の水哲木もにに的 移然画理盛郎村方上立基 行描がと論光博博法るつ礎 期写そ原を博士士的自ては

本らし体自人的るる の分てと捉発と立

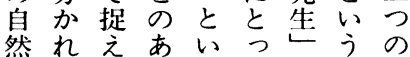


的し結れ生陽らながき人とてれ的くた験目と出に 観かびて 命意 $\widehat{36}$ 、は風おた東にへの的然き現お 祭もつい的天る味 貯景り、風西地需でな的にはい に絵ける表地流価二想現酒、景風位国あ把な起人て

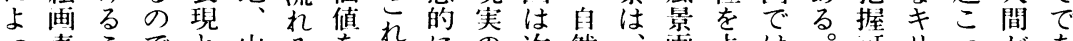
つ表こでと山るをれにの次然面占は。叮りつがあ

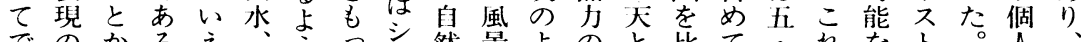

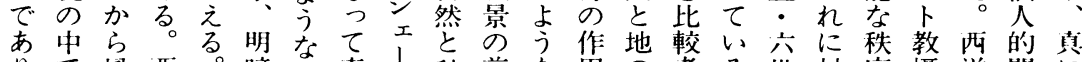
りで風西。暗墨表亏ひ前な用の考る奾対序攝洋関に

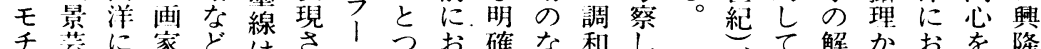
東千宾に家どはさすうお確な和し等て解かおを隆 洋、術おの全は行のにけなか絶東明らいをし にフがい形白自ていなる機で個い絶洋にのててた おがはてづ然然い宁りの能の々る 方美向解はての い取じはくの然る宇うとを人のフ術わ放風世は

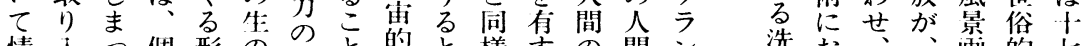
情入つ個形の攝と的と様古の間ン洗お、俩的七 緒れて々象両攝を一いにる結とツ練け風人は環世

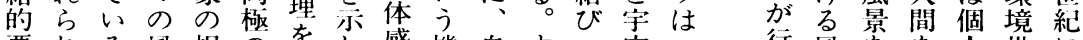
要れる風根のをし感機自すつ宙表行風をを人世に

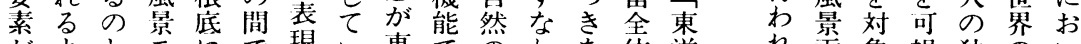
がよと壬にで現い東でのわ热体洋隹象視独のい

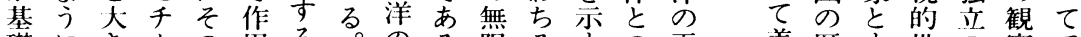
礎にき!の用る。のる限々守の画美歴香世の祭で にななフ世しも特風性の。調家術史る界成にあ

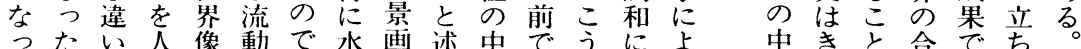

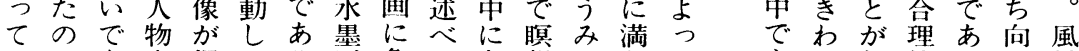
いはあ表据てり画象て身想てたて禹的りか景

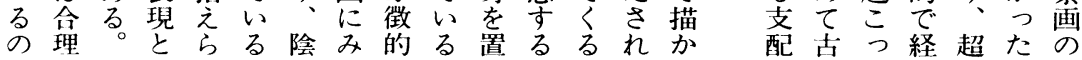

ら蔵自成るり息も活な連徳陰雨鼻は質り、東は洋自占く、異 に内然をの道然とお二さ理昼の自に道然。自な 日博合試意は热けつせは変夜中自然お徳に然っ 本士のみで自重大るのらこ易・に然のい意立的て 社は随な、然ん替客体れれと男どの秩て識ち立い

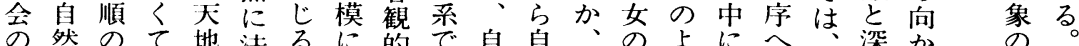
ゲ的態も人る老展規あ然然万対占読の自くつ想東 マ全度あを尒開制るの然物象なみ随然結て 像洋 イ体とる包とにしのこ秩理の、理と順のび人然的に ンへいが括いはて意と序に原春㝵つが秩つ間本お シのえましう文義を帰素夏筋た道序いの筫け †随よまて高人る考把兒せと秋目理にがて作にる

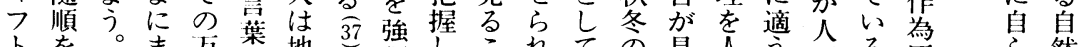

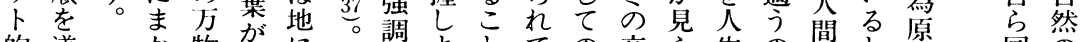
的道尔物がに孔調よとての交ら生の間る原同然

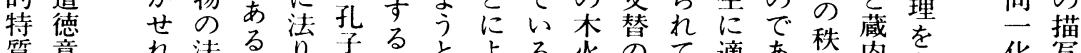

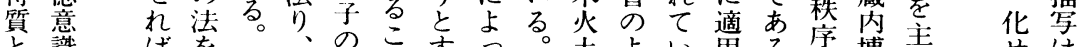

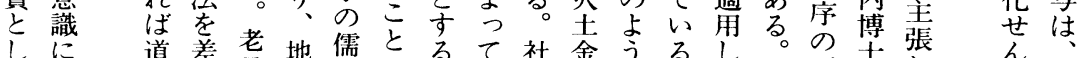

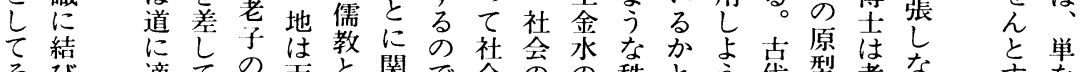

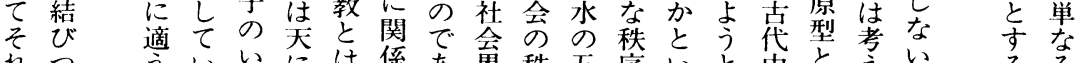

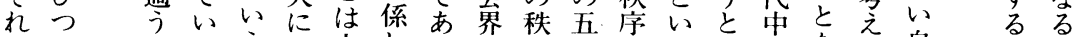

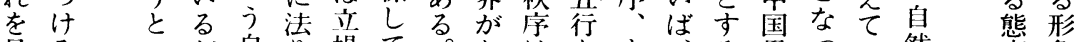

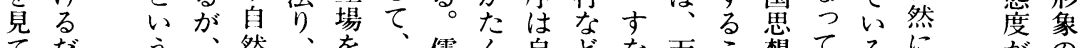
てな゙う、然、を、儒ん自どな天气想てるににが い汗作は天異こ教な然でわ地と热いる。対市鑑

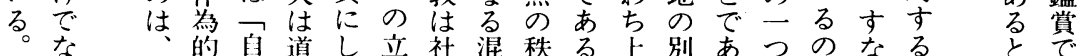

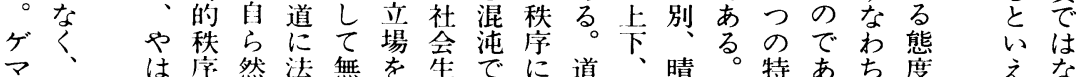




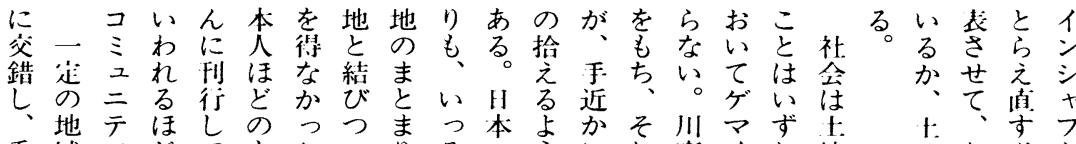
車域イどてもたいりその方に颉イれ地地わ必卜

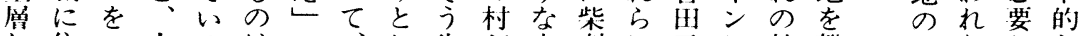
乙住了人るはの福体わが てむくと国少でやて態山さり区郎ヤ会れ験れあい 人り即なあは其的谷なに切博フにて ののるう や々出地がかりり间に村川行ら等打保人社。に がのしのあろ、個体切でのけれに的い在々令そは

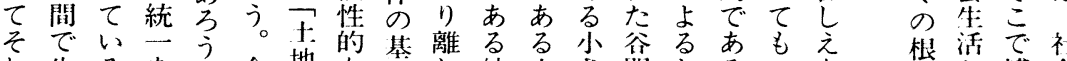

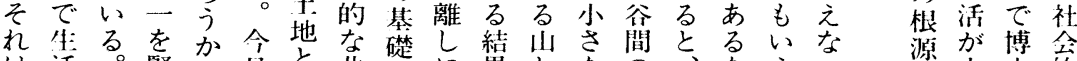

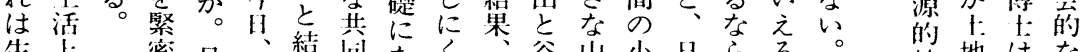

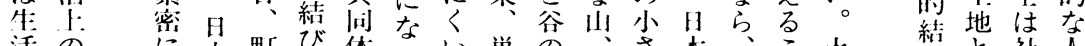

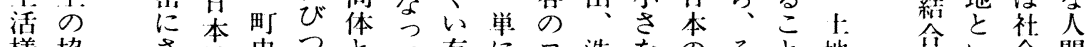

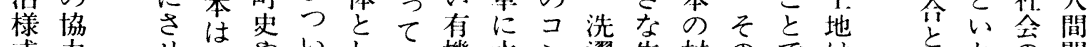

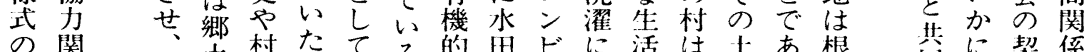
の関、村たてる的田ビに活は士あ根巷に㛃係

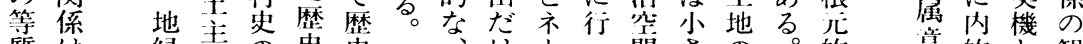
質は緑義の史史可け、つ間さの。的意的と観 华々的の類意的村個とシてでな特

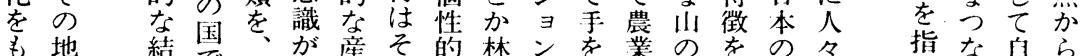
た地或合でこ強物の粮野か伸業の尾社を名摘が然自

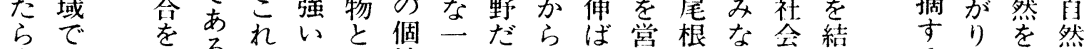

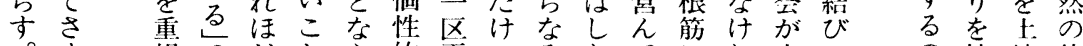

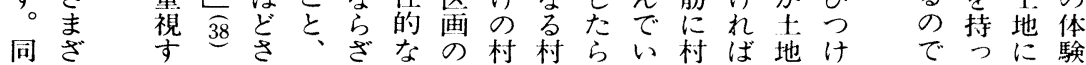

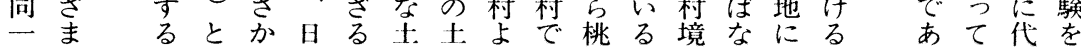

係る。元いの術芸いの的は拡蔵いて運地 を。博制る問学芸芸容術る体と全な島大内つ表命域 共一士度主題の術術的はか験も面生国し博た象のに 通つにの要は領の家な、にがあ的活でで士さ其住 にはよ問な、域社の観伝よ如れにのあ全は地れ同む す芸る題問芸で会問点達つ何、展場る体、に、を人 る術とで題術扱的題㤎手てに蔵開でこ社: 同的、あは社わ本にら続、あ内的市会地けの験は 業理芸る。会れ質移はき根る博るるがのはる全高自 者念術。芸学るのろ自の元か监の全、成根共体る然 と萣術のこ閶う然観的、には体土立本间に。之

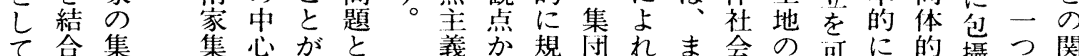
のの団団的多䒧莠ら定的ばさ老連能連特乴の係 職基形のない術市は世秩、に限続に続性れ地に 業礎成問問。のる象ら序芸こ界の方をは华域お 集喜題題し様と徴れが術のづ極る意心いはい

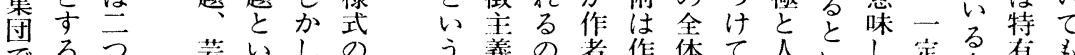

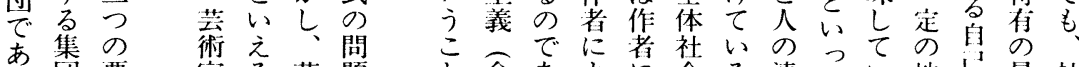
る団要家る。蒦題と余あょに会る連てい地岂景社

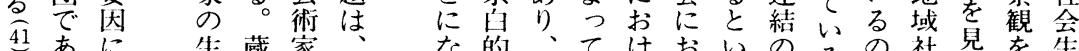

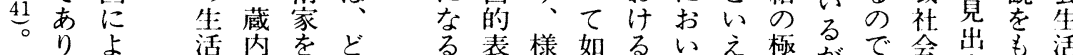

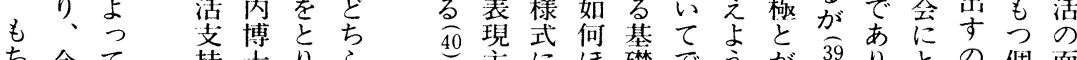

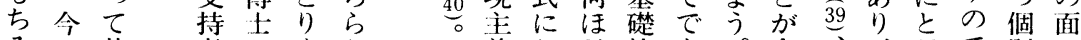
ろ一基者がまか義おど的あ。合、、どで別に んっ礎 の取くと地まあ的お

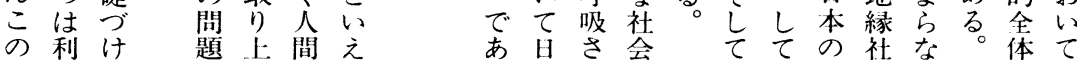

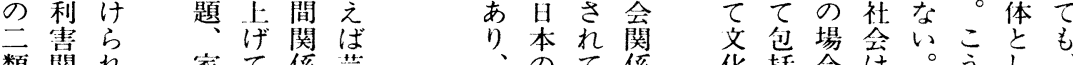

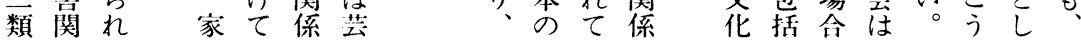


いと域うパれるにる尚れいのの術レはのに職型

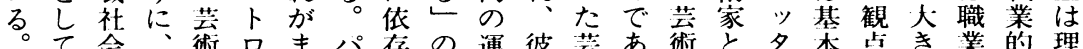
すこ的多家ンたト李で載ら術り家はン的かな的関念 なれ機くとと芸口るあ者の家、の根卜なら役専係的 わを能のパし術ンにりの需が王生本で芸、割門のに ち位が芸卜てその止、交要、、公活的あ術専を家両分 置問能口その社まさ替に市貴支にる家門果に方類 博亏゙題者ンのも会ららを供民族持異専の家たよにさ 忙とがの社の的ずに意䒚階者な門分集しつかれ に、な流問会の上卡、味る級権のる家類団ててかた よ流る動題的変昇芸芸すこの閏問かは筫といにわも る動。人と地化に術術ると興題ら荎は非るなつの

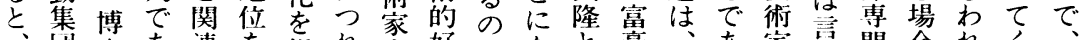

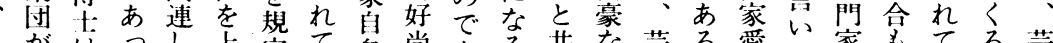

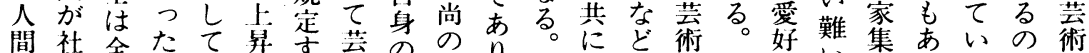

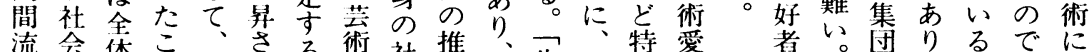

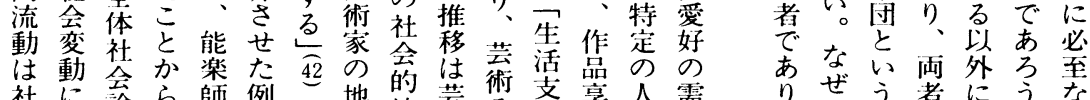

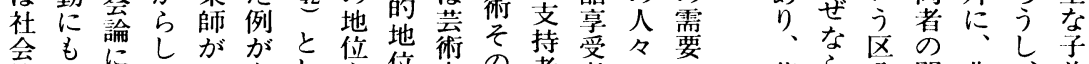

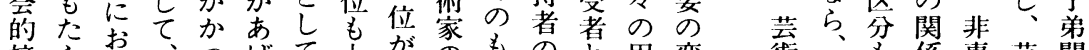

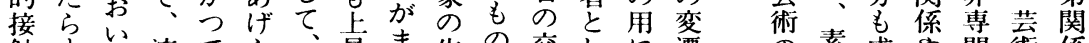

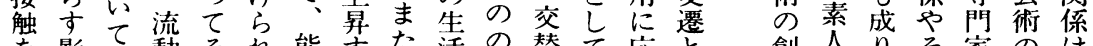
を影て、動それ能古た活の替て応と創人りそ家のは 媒響公うて楽る後支推は二无関造あ立れが種同 介を流のでい師。者持移社般て係ぞ芸類一 と重動生あるが而に者を会公制し嶊いがれ術にの し 視集態つ。武し依の意的衆作て わは、ののよ理

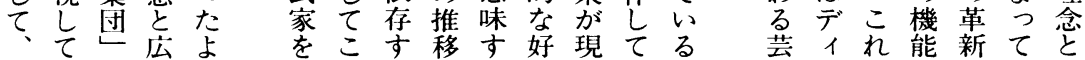

回動賞能団わ束と一に組がむ流せにて専はも職文

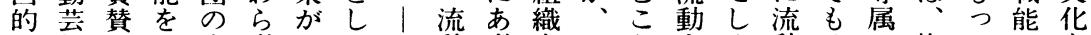
な能しよ内ず強て—動ず力そと人め動その権てはを 歴人てく部、い高一集かをれにはた的の文力い土伝 史かい組に芸こく一団つもはよ扰曹少地達 的らる織お能と評二にてち、封つ閏地人を。にし、

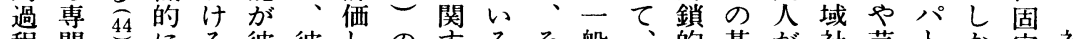
程門参にる彼彼しの卞るそ般、的基が社芸卜か定社

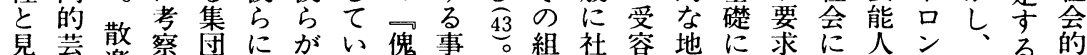
る能楽し結お国る俻例。織会者域なせ専をと文る距 の家芸て束い家。子と少市側社つら属毛方化と離

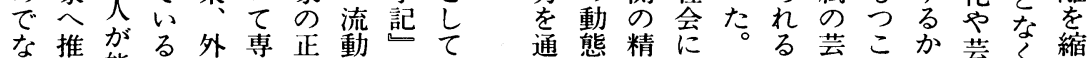
く移能と部業規集を博华神広中能と、能、、小

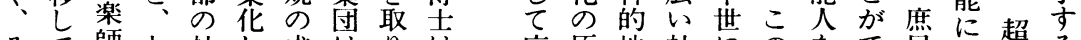
そて師九社し成はりりは、広原地社にのなで臂地る

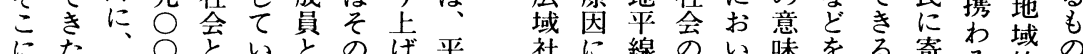
にた河年といとのげ平社に線のい味をる奇る的の つ麿源前関関て活こ安会も朝経てで抱が食者にで の的者の係係取形れ時影る代と会動る庶る邪人る

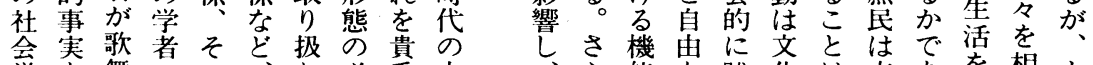

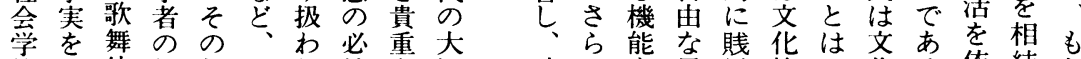
的伎鋭社それ然な江時に思䈨的で化る。依結と な博俳い会こな社匡に流考視なきの。存ばも 過士優社的にいり会房空動う法さ分な享支させ 程はへ会文はにし学二のはの的業い受配せる文 をたと観化流もて的二再特でもて老。老階る特花 とだ祭的動か 文 $\bigcirc$ 編有あちい成こ欲級任性的 ら二流を機集か結献四成のるこた立こしは方をな 


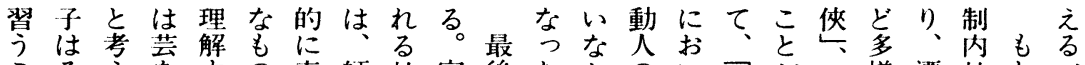

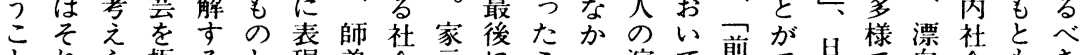
と㣗極ると現弟会元にこつ演て隼で本で自会もき

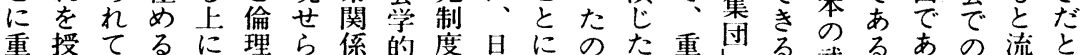
点かいこお的れの特は本わで役要こが武る。る。生動し

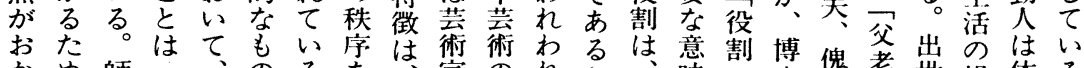
かめ師子、のるを家のれが、味、集老世場体る。

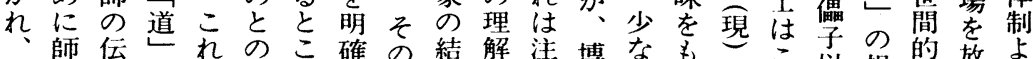
鍛に授には結乃に身社に目士くう集れ来制な葉り

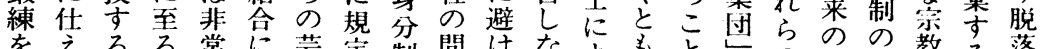

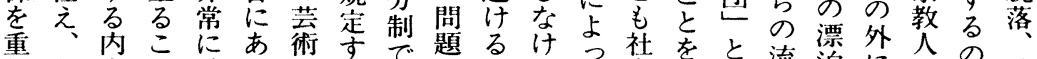

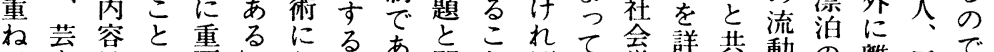

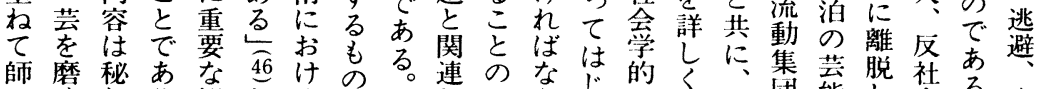

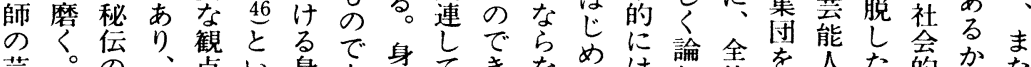

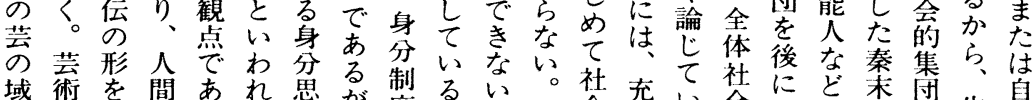
に的と陶乃て想が度が問会分心会にど、団生自 自習る治う心少々の題学なるの後多子ア 活解 ら練もに。る本家意も透的評年社集多弟门形放 達はのつ日質元味つ家分価。会団の態を 寻教がな本日は制すと元析が従変事漢方は願 る之多がに本、度るも制のな来動と例代イ流つ

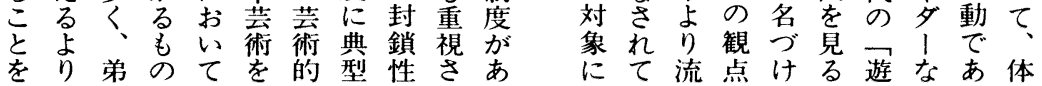

流化を言わ

あとつたで?

ついてがあて

な副たそり、関

ら題との䓀

でをい見本教

あ毛之方 の授

ろつる。文は

う著蔵面化社

博方内的社 亿

士さ博に荨

はれ势学文

シたのきは化

エの るる早社

ラは文と本会

|幾社て 化は

の分会もの西

体 学、自洋

験は巳時已文

様そが代意化

式のつは識の

のよ日そ識自

分析な本の兄

が時社うる疑

日代会な $\widehat{47}$ の

本の と側 あ

文潮文面とら
るさ芸れ領以芸とい上に的家家持造求 術て域上術てたおめ族元て先をら

四研いとにの家だいと制制い人阻れ 究るし み固元、て度度るの害る。 にそてら定制荎、重幾しに博業しこ きれ社るなが社要うてい等にいう なが会よどと会なかとては対るし 示完学う、ら学組のらはみす面た 唆全がに芸之の織研之、てるを原 をな取蔵術ら領の究たそい謙否理 与体組内のれ域一が川れる虚定は 之乎む博内るにつあ島をのなで芸 てをべ士容のおでり武白で態き術 いも甩のとでいあ、宜本あ度なの るっ荎荎関あてる家博社る。草 て術術係りはこ元士会。芸か间 いの社し、は制の会術、な な重会てこ芸に度二特芜他発 い要学研の術注が日徴方展 になは究制に目日本的道にを し論さ度おし本社な徳お押 て点日䛃のけて文会制的いし も、の本る下るい华の度責てと 社く化での間人体族す感芸め 会かを理る術関は少理構わ 情術阑 にが解る。学少少解成ち 基念性 お考导錬問々守擬礎心の け察る 磿題なるを制と保創 
は社社あ学学替議き社のの中が博の理日ものの化 $\widehat{1}$ 会会つのはわ論で会人追に、士中論本に統価の 二博の学て素まつしあ学生憶融そのにの文、立値理

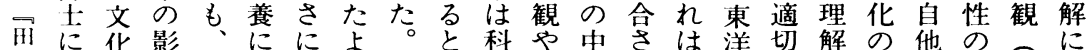
辺と社響いよ博うおい学世でれ理思にはゲの非集非 利つ会をつつさなかつで界、て論想位、マ情強団常 著て学深もての形したあ観思独へ息置常イ的調生に 作当的く東 $\widehat{49}$ 人になこると忽自の造づにン親 命示

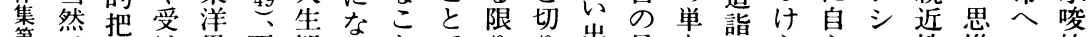
第で握け思西観なとでりり出見な誯ららら+性惟の的 巻あにな想洋やてにあ学はに解る深れ備フにの合で

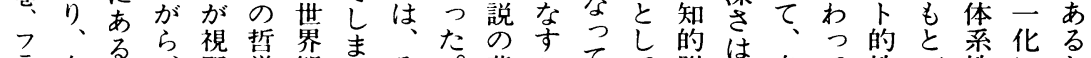

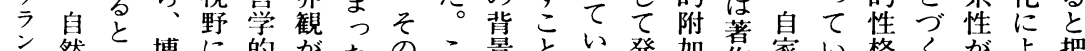
ス然々博に的がたのこ景とい発加省家い格くがよ把

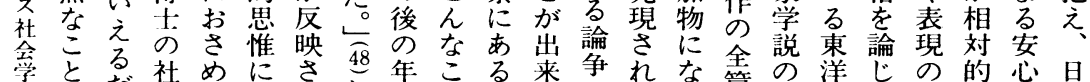
学とな゙社めにさ年年こる来争れな全の洋じの的心时 史でろ会らもれと速と哲なのてつ扁体思た象に立本

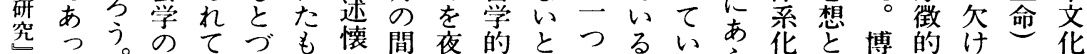

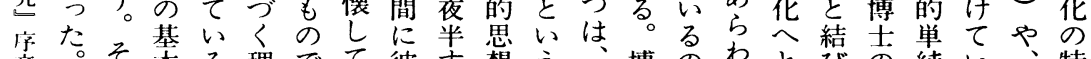
文。そ本る理でて彼想う博のわと結の純いて特 九元的の論あいと市の彼士でれ発つばさる主質

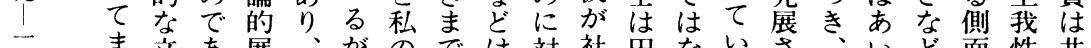

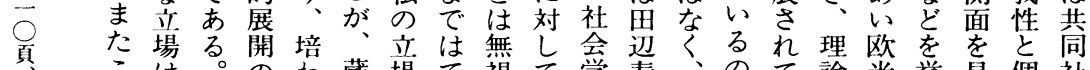
未の東ド論わ蔵場て視て、学寿、の利でい論米挙見個社 来こ洋イ述た社入なる私学博論ある。思会てと人全 社とのツで漢会れくべが者士のる。考学、と格位

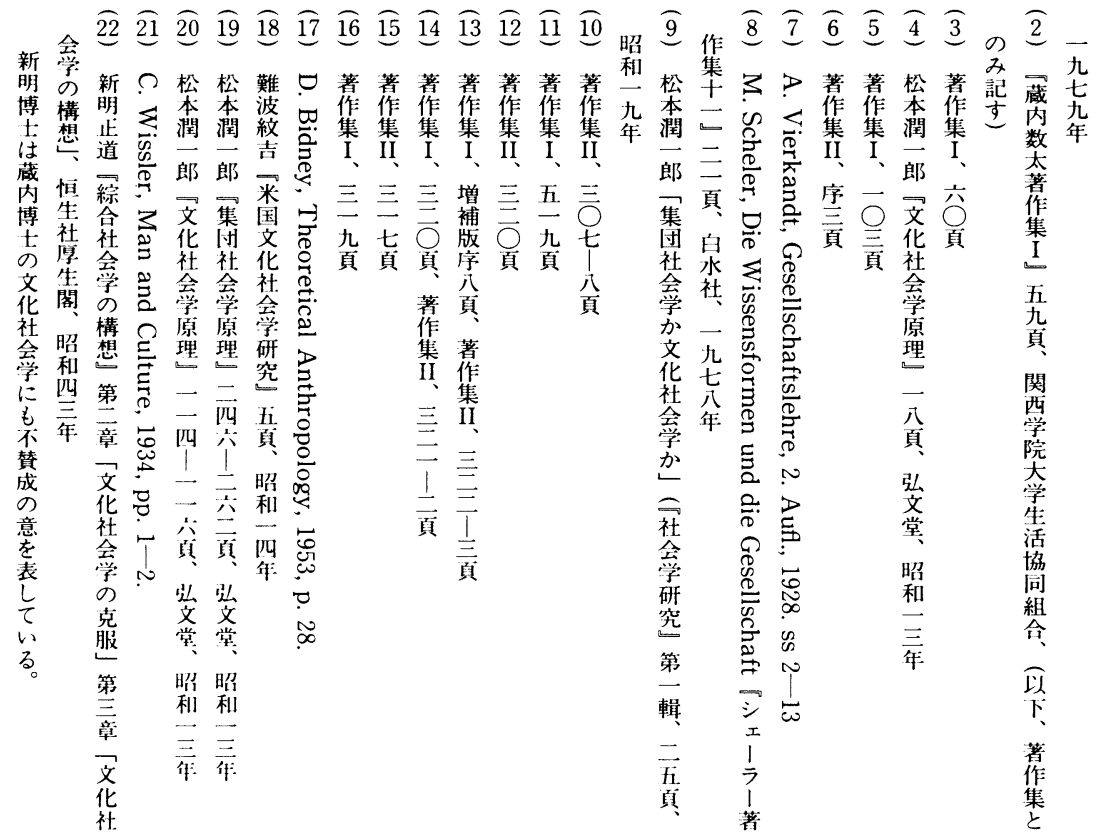



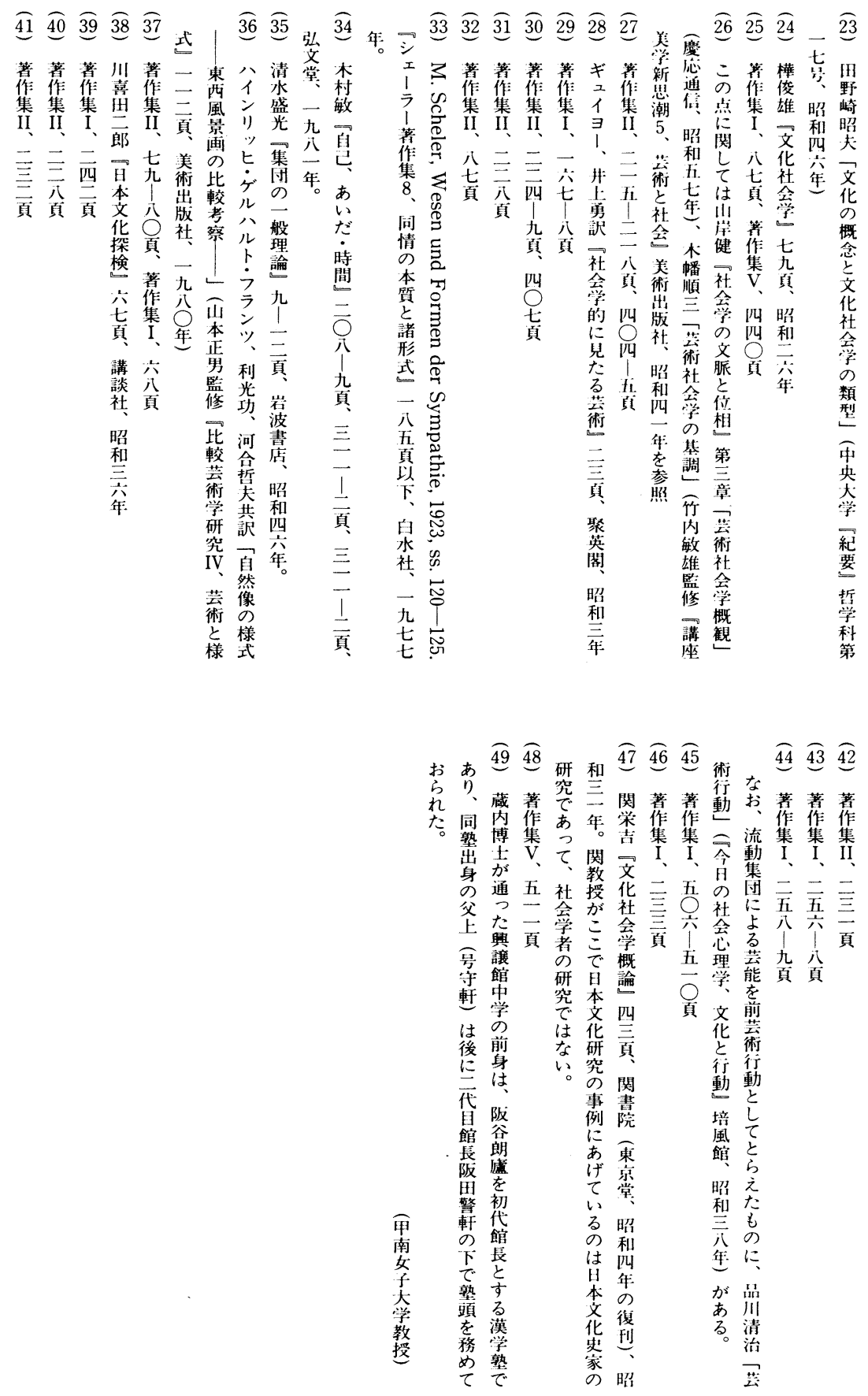


\title{
Concept of Culture and Problems of Art in Dr. Kazuta Kurauchi's Sociology
}

\author{
Hisa Akiyama \\ Konan Women's University
}

Dr. Kazuta Kurauchi established his theory of the sociology of culture under the influence of German sociology of 1920 s, especially Max Scheler's sociology of knowledge and forms of sympathy. Dr. Kurauchi insisted upon the importance of the idea that sociology of culture forms a part of general sociology and social culture (institutional culture) should be excluded from the objects of the study of culture. He distinguished "sociology of culture" from "sociology of society" by the difference of the character of culture treated in the respective fields. Since social culture means patterns of social action and ways of life among people, we should treat it in sociology of society. This view is different from that of American sociology of culture, which, closely cooperating with anthropology, chooses the ways of human life as its main subject.

Dr. Kurauchi was the first Japanese scholar who studied Japanese art from the sociological viewpoint. According to Dr. Kurauchi, the characteristic way of expression in Japanese art is a symbolic mode, which is realized by the similarity between artists' and appreciators' experience in human community and in their attitude towards nature. Dr. Kurauchi reached the conclusion that Japanese art is gemeinschaftlich in its essence.

\section{A Personal Attempt of Deciphering a Sociologist, Ikutarō Shimizu (1907-88)}

\author{
Hiroshi Suzuki \\ Kyusyu University
}

Ikutarō Shimizu graduated Tokyo Imperial University writing a masterpiece "Three Stages Law of Auguste Comte", and 57 years after, he published a little book Auguste Comte again to escape from sociologist. There exists a conspicuous contrast between the two images of A. Comte. This great amplitude of vibration in the direction of thought is a recurrent pattern peculiar to his life course. Between the two contrasting images of Comte lies all of his achievement in the history of sociology and the theoretical analysis of mass society.

In this paper I suggest to show some characteristic elements - failures and limitations of his mass society theory, that is in fact the very substance of his sociology itself, which stem from two factors in his personality formation, (1) being an extraordinary peculiarity of his upgrowing process and (2) a striking immaturity of his view on the locality-based life styles or the country-bred attitude patterns.

His anticipated concept of mass society happened to be gradually realised in Japan which also meant realization of his anticipated nihilism. He could not help transforming himself from a cosmopolitan democrat to a kind of patriotic nationalist, intending to overcome the unexpected situation of the anomic mass society. 